Egyptian Journal of Aquatic Biology \& Fisheries

Zoology Department, Faculty of Science,

Ain Shams University, Cairo, Egypt.

ISSN $1110-6131$

Vol. 23(1): 105 - 133 (2019)

www.ejabf.journals.ekb.eg

\title{
Distribution of benthic foraminiferal assemblage and heavy metals as a characterization of the environment in Lake Edku, Egypt.
}

\author{
Rehab Elshanawany ${ }^{1,2^{*}}$, Bassant Naiel $^{2}$ and Manal Fawzy ${ }^{2}$ \\ 1- Marum, Leobener Straße, University of Bremen, D-28359 Bremen, Germany. \\ 2- Faculty of Science, Alexandria University, Egypt. \\ *Corresponding author: rehab_shanawany@yahoo.com
}

\section{ARTICLE INFO \\ Article History: \\ Received: Nov. 22, 2018 \\ Accepted: Jan.22, 2019 \\ Online: Feb. 2019}

Keywords:

Benthic foraminifera

Lake Edku

Heavy metals

Pollution

Sediment

\section{ABSTRACT}

Lake Edku receives considerable amounts of domestic, agricultural, and industrial waste water. Accordingly, the response of benthic foraminifera to heavy metal pollution has been assessed. Surficial sediment samples were collected at 11 stations throughout the lake during June and December 2013. At each station, $\mathrm{pH}$, dissolved oxygen, temperature, salinity, transparency, water depth, concentrations of $\mathrm{Pb}, \mathrm{Cu}$ and $\mathrm{Cd}$ were measured. Benthic foraminiferal distribution and its relationship with environmental parameters and heavy metal concentrations have been investigated using redundancy analysis (RDA) and cluster analysis. The resulted data show that the foraminiferal distribution was significantly affected by these heavy metals pollution. The distribution pattern shows great dominance of Ammonia tepida which confirms its tolerance to heavy metals pollution especially $\mathrm{Cu}$ and $\mathrm{Cd}$. Porosononion spp. correlates positively with $\mathrm{Cu}$, while Saccorhiza ramosa correlates positively with $\mathrm{Pb}$ and $\mathrm{Cd}$. The most sensitive species to higher concentrations of heavy metals is Ammonia Parkinsoniana. It has negative correlation with $\mathrm{Pb}, \mathrm{Cu}$ and $\mathrm{Cd}$. Limited number of living foraminiferal specimens, low foraminiferal density and diversity have been recorded in Lake Edku. Relatively high percentage of deformed foraminiferal tests $(\sim 21 \%)$ has been observed in the lake.

\section{INTRODUCTION}

Coastal ecosystems, including coastal lakes, have been impacted by several human activities such as urban sewage, industrial and agricultural activities or fisheries, and results in environmental problems, such as eutrophication, oxygen deficiency, chemical pollution or physical disturbance (Barras et al., 2014). Heavy metals are dispersed throughout the modern environment mainly as a result of pollution from a variety of industrial sources and continuously enter the aquatic ecosystem where they pose a serious threat because of their toxicity, long persistence and bioaccumulation in the food chain (Papagiannis et al., 2004; Abdallah, 2012). Heavy metals, unlike other pollutants, are not biodegradable and can accumulate in sediments overtime (Tang et al., 2008). Sediments act as a major repository for many natural and anthropogenic contaminants entering the coastal marine systems and can preserve a record of the pollution sources and pathways (Campbell and Tessier, 1989; Degetto et al., 1997). 
Among all the benthic microfauna, Foraminifera (class Foraminifera, phylum Granuloreticulata) are the more abundant and most conspicuous protozoa in most marine and brackish water habitats (Murray, 1991; Armynot du Châtelet et al., 2004). The utilization of benthic foraminifera as pollution indicators has many advantages, as they are easy to collect. They have short reproductive cycle (the majority between a few months and a year), which increase their ability to reflect relatively short- to long-term variations. They are small and are often found in high biodiversity and density populations, providing an adequate statistical base. Their mineralized tests readily preserved in the sediments providing an evidence of environmental stress through time. Benthic foraminifera are very sensitive to rapid physicochemical variation in the environment (Alve, 1991; Coccioni, 2000; Yanko et al., 2003; Armynot du Châtelet et al., 2004; Frontalini and Coccioni, 2008; Frontalini et al., 2010). The application of foraminifers for pollution assessment is based on the variation in population assemblages, total foraminiferal number, species diversity, and abnormalities of the foraminiferal tests in the areas affected by pollution (Jayaraju et al., 2008; Elshanawany et al., 2011; Foster et al., 2012; Cosentino et al., 2013; Martins et al., 2013; Barras et al., 2014). The responses of foraminifera can include local extinctions, resulting in a barren zone where polluted levels are high, as well as assemblage modifications with increased density and low diversity (Yanko et al., 1994; Alve, 1995; Cearreta et al., 2002; McGann et al., 2003; Frontalini and Coccioni, 2008). Moreover, other studies investigating the response of foraminifera to pollution have shown that a lower density and diversity occurs in the most polluted areas (Alve, 1991; Armynot du Châtelet et al., 2004; Ferraro et al., 2006; Romano et al., 2008; Armynot du Châtelet and Debenay, 2010; Frontalini and Coccioni, 2011; Cosentino et al., 2013; Martins et al., 2013). Several studies have been focused on benthic foraminiferal response to trace element pollution all over the world (in western Norway e.g., Alve, 1991; in Italy e.g., Coccioni, 2000; Ferraro et al., 2006; Frontalini and Coccioni, 2008; Coccioni et al., 2009; Frontalini et al., 2009; 2010; Frontalini and Coccioni, 2011, in France, e.g., Armynot du Châtelet et al., 2004; Foster et al., 2012, in Portugal, e.g., Martins et al., 2010; 2013; in the Central Mediterranean Sea e.g., Cosentino et al., 2013; in China, e.g., Li et al., 2014; 2015, in the Murter Sea e.g., Vidovic et al., 2014). Along the Egyptian Coast, some related studies have been done (e.g., Samir, 2000 in Edku and Manzalah Lakes; Samir and El-Din, 2001 in El-Max and Miami Bays; Elshanawany et al., 2011 in Abu Qir Bay; Orabi et al., 2017 in Burullus lagoon). The previous studies in Lake Edku were dealing with physical and chemical characteristics (Shakweer, 2006; Badr and Hussein, 2010; Abdel Halim et al., 2013; Khalil and Rifaat, 2013). Persistent organochlorine pollutants, metals residues in sediment, water, freshwater fish species and aquatic macrophytes were also investigated (Badr and Fawzy, 2008; Barakat et al., 2011; Shreadah et al., 2012; Abdallah and Morsy, 2013). Unfortunately, foraminiferal data in Lake Edku was very few (e.g., Samir, 2000). In this previous study, the data was limited to few station numbers (five stations) and the seasonal aspect has not been covered.

The aim of this research is to test the suitability and applicability of using benthic foraminifera as bioindicator of heavy metal pollution and pollution monitoring in the studied lake, investigate the distribution and abundance of benthic foraminifera in relation with different environmental parameters and heavy metal concentrations in the sediments. Moreover, foraminiferal seasonal changes will be assessed in this study.

\section{Study area}


Lake Edku is a shallow brackish coastal basin situated on the western margin of the Nile Delta, $30 \mathrm{~km}$ to the east of Alexandria. It lies between longitude $30^{\circ} 8^{\prime}$ and $30^{\circ} 22^{\prime} \mathrm{E}$ and latitude $31^{\circ} 10^{\prime \prime \prime}$ and $31^{\circ} 18^{\prime} \mathrm{N}$. Its area has decreased from $28.5 \times 10^{3}$ to about $12 \times 10^{3}$ Feddans as a result of agricultural reclamation (Abdel Halim et al., 2013). The bottom sediments of Lake Edku are rich in silt and clay in the eastern part, and sand near the Lake-Sea connection. A transition zone of shelly mud is found in the central part of the Lake (Ibrahim, 1994). It receives its water from two drains namely: El-Khairy and Barsik. El-Khairy and Barsik Drains discharge huge amounts of drainage waters to the lake. The water sources of El-Khairy Drain are from three drainage waters transporting domestic, agricultural and industrial wastes, as well as the drainage water of more than 300 fish farms. Barsik Drain transports mainly agricultural drainage water to the lake. (Badr and Fawzy, 2008; Badr and Hussein, 2010). The lake receives seawater at its northwestern part through Boughaz ElMeadia from Abu Qir Bay. In recent years, waste waters from industrial and domestic activities have been directly released into Lake Edku in increasing quantities through the drains network, without any pre-treatment. A rapid rise in petro-refineries and fertilizer manufacturing industries is the major source of pollution in the region. Relatively low depth and slow water exchange make contaminants available at higher concentrations (Abdallah and Morsy, 2013) (Fig. 1).

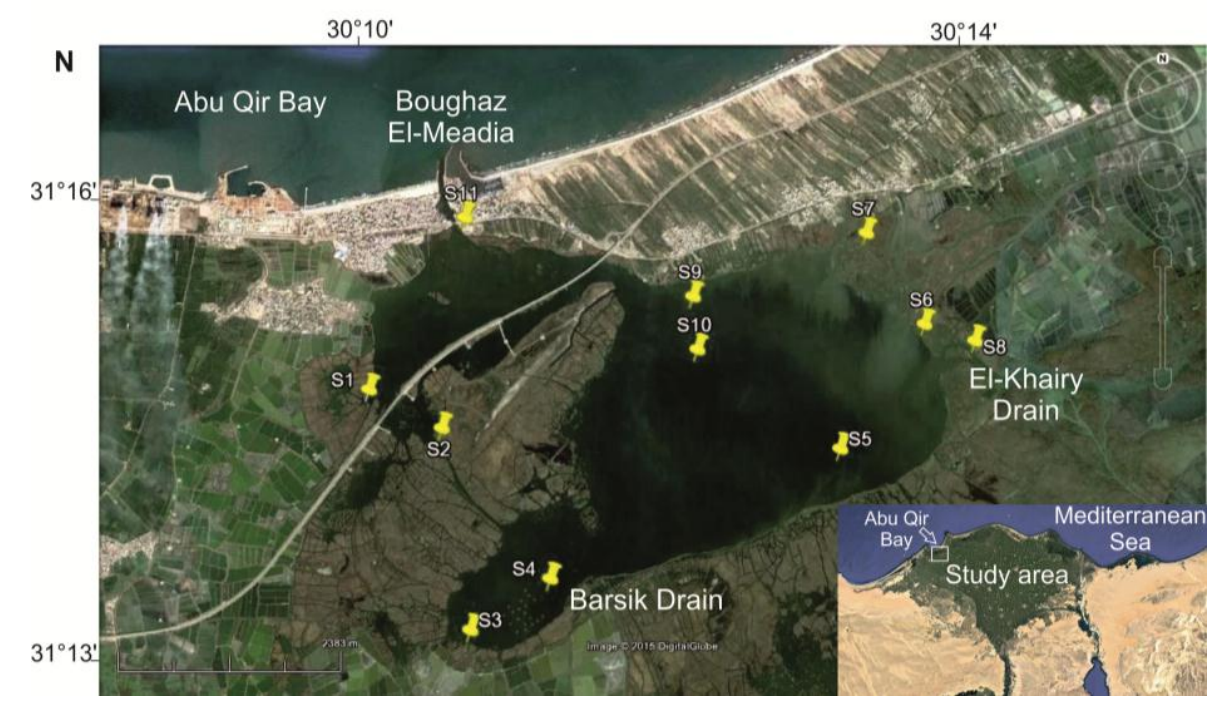

Fig. 1: A Satellite image of Lake Edku showing location of sampling stations.

\section{MATERIALS AND METHODS}

\section{Sampling and sediment preparation}

Surface sediment samples were collected seasonally from 11 stations (S) in June (J) and December (D) 2013 with a stainless steel grab. Sampling locations were determined with Global Position System. Two aliquots from each sample were taken at each station. The first was stained with Rose Bengal and used through the study of foraminiferal assemblages and the second to measure trace element contents in the sediment. At each station, $\mathrm{pH}, \mathrm{DO}$, temperature, salinity, transparency and water depth were measured.

\section{Heavy Metals analysis}

Metal content in the collected samples were determined using acid digestion adopted by Wade et al. (1993); $0.1 \mathrm{~g}$ dried sediment samples were digested with $3 \mathrm{ml}$ 
$\mathrm{HNO} 3$ and $2 \mathrm{ml} \mathrm{HF}$ for $24 \mathrm{~h}$ at $130^{\circ} \mathrm{C}$ in a closed Teflon vessels, then $17 \mathrm{ml}$ of boric acid 5\% was added to the mixture and diluted up to $25 \mathrm{ml}$ with distilled water then the mixture was stored for analysis. Concentrations of $\mathrm{Pb}, \mathrm{Cu}$ and $\mathrm{Cd}$ were determined using SHIMADZU Atomic Absorption Spectrophotometer AA - 6800. For quality control (QC) and quality assurance (QA), a standard reference material was also digested and analysed similarly to ensure the accuracy of the heavy metals analysis.

\section{Foraminiferal analysis}

A constant volume of $50 \mathrm{~cm}^{3}$ of sediment was taken from the upper $2 \mathrm{~cm}$ of each sample and saturated with a solution of Rose Bengal following Walton's technique (1952) to distinguish between living and dead foraminifera. In the laboratory, samples were gently washed through a $63 \mu \mathrm{m}$ sieve with tap water to remove clay, silt and any excess dye. The residual fractions obtained were oven-dried at $60^{\circ} \mathrm{C}$ overnight. Whenever possible, at least 300 well-preserved benthic foraminifera from each sample were picked, counted and classified under a binocular microscope. Species were identified by comparison with Cimerman and Langer (1991), Sgarrella and Moncharmont-Zei (1993), and supraspecific classification was based on Loeblich and Tappan (1987). All deformed tests, whenever present, were picked from each sample and morphologically examined.

\section{Statistical analysis}

All statistical analyses were performed on foraminiferal relative abundance data; only species showing relative abundance greater than $2 \%$ in at least one sample was used. Cluster analysis was performed using version 1.88 of PAST software package (Hammer et al., 2008). A Q-mode analysis (sample by sample) was used to produce a dendrogram classification of studied samples, while R-mode analysis was used to produce a dendrogram classification of species to group samples, according to their similarities or differences, in multidimensional space (Murray, 2006). In Q and $\mathrm{R}$ mode analyses, the correlation using Spearman's Rho was applied.

Diversity of the foraminiferal assemblage was determined using version 1.88 of PAST software package. Four diversity modes were used. The dominance (D), Simpson index, the Shannon diversity $(\mathrm{H})$, and Fisher's alpha $(\mathrm{S})$ were calculated as defined by (Hammer et al. 2008), applying the equations $D=\Sigma(n i / n)^{2}$, Simpson index $=1-$ dominance, $H=-\Sigma(n i / n) \ln (n i / n)$, and $S=\alpha \ln (1+n / \alpha)$ where $n i=$ number of individuals of taxon $i, n=$ total number of individuals, $S$ is number of taxa, and $\alpha$ is the Fisher's alpha.

A Detrended Correspondence Analysis (DCA) was performed to test, whether species exhibit a unimodal or linear response to an environmental gradient (Leps and Smilauer, 2005; Leyer and Wesche, 2007). Redundancy Analyses (RDA) were carried out to quantify the relationship between the distribution of benthic foraminifera and ecological parameters such as heavy metal concentrations, water depth, $\mathrm{DO}, \mathrm{pH}$, temperature and salinity, using the software package Canoco, version 4.5 (Ter Braak and Smilauer, 2002; Leps and Smilauer, 2005).

\section{RESULTS}

\section{Environmental parameters}

In the present study, the recorded depth of the investigated stations ranges from $0.43 \mathrm{~m}$ at $\mathrm{S} 2$ to $2.5 \mathrm{~m}$ at $\mathrm{S} 11$ (Boughaz El-Meadia) in June and ranges from $0.26 \mathrm{~m}$ at S8 (El-Khairy Drain) to $3.32 \mathrm{~m}$ at S11 in December (Boughaz El-Meadia). Boughaz El-Meadia station (S11) is the deepest station in both seasons. S8 and S2 have the 
lowest depth in December. Generally the water depth is low in both seasons especially in December, but it increases towards Lake-Sea connection (Table 1).

Water temperature undergoes huge seasonal variations but it has narrow spatial variations in both seasons. It has a range of $15.3^{\circ} \mathrm{C}$ at $\mathrm{S} 5$ and $17.9^{\circ} \mathrm{C}$ at $\mathrm{S} 11$ in December. It ranges from $26.7^{\circ} \mathrm{C}$ at $\mathrm{S} 1$ to $29.2^{\circ} \mathrm{C}$ at $\mathrm{S} 7$ in June. Temperature is higher in June than in December (Table 1).

Water salinity of Lake Edku has a general spatial increasing trend towards Boughaz El-Meadia and S1and a seasonal increasing trend in June. It ranges from $0.8 \%$ at $\mathrm{S} 7$ to $5.5 \%$ at $\mathrm{S} 1$ in June and from $0.1 \%$ at $\mathrm{S} 8$ (El-Khairy Drain) to $0.9 \%$ at S11 (Boughaz El-Meadia) and S1 in December. Station 1 and S11 have the highest salinity values in both seasons. On the other hand S7 and S8 (El-Khairy Drain) have the lowest salinity value in June and in December respectively (Table 1).

The $\mathrm{pH}$ values in the investigated stations have small spatial and seasonal variations. It ranges from 7.7 at S4 to 8.82 at S11 in June and from 7.33 at S8 to 8.49 at S4 in December (Table 1). The data show that the water of Lake Edku is slightly alkaline.

Lake Edku is oxygenated with a range of $2.51 \mathrm{mg} / \mathrm{l}$ at $\mathrm{S} 8$ and12.51 mg/l at S3 (Table 1).

The Water transparency of Lake Edku increases toward the Mediterranean Sea at $\mathrm{S} 9, \mathrm{~S} 10$ and $\mathrm{S} 11$ as the depth increases. It has a range of $16.5 \mathrm{~cm}$ at $\mathrm{S} 6$ and $86.5 \mathrm{~cm}$ at $\mathrm{S} 9$ (Table 1).

Table 1: Environmental parameters in the investigated stations of Lake Edku during June and December 2013.

\begin{tabular}{|c|c|c|c|c|c|c|c|c|c|c|c|}
\hline Stations & Latitude $(\mathrm{N})$ & Longitude (E) & Depth (m) & Temperature $\left({ }^{\circ} \mathrm{C}\right)$ & $\mathrm{pH}$ & DO (mg/l) & Transparency $(\mathrm{Cm})$ & Salinity (\%) & $\mathrm{Pb}(\mu \mathrm{g} / \mathrm{g})$ & $\mathrm{Cu}(\mu \mathrm{g} / \mathrm{g})$ & $\mathrm{Cd}(\mu \mathrm{g} / \mathrm{g})$ \\
\hline S1J & $31^{\circ} 15^{\prime} 00.4$ & $30^{\circ} 10^{\prime} 09.2$ & 0.93 & 26.7 & 8.28 & - & - & 5.5 & 89.35 & 30.96 & 0.000 \\
\hline S1D & $31^{\circ} 15^{\prime} 00.4$ & $30^{\circ} 10^{\prime} 09.2$ & 0.41 & 16.0 & 8.09 & 8.51 & 20.5 & 0.9 & 76.58 & 24.10 & 0.000 \\
\hline S2J & $31^{\circ} 14^{\prime} 46.8$ & $30^{\circ} 10^{\prime} 39.2$ & 0.43 & 27.6 & 8.46 & - & - & 1.8 & 116.15 & 48.46 & 0.000 \\
\hline S2D & $31^{\circ} 14^{\prime} 46.8$ & $30^{\circ} 10^{\prime} 39.2$ & 0.38 & 16.5 & 8.33 & 9.38 & 17.0 & 0.3 & 72.75 & 25.45 & 0.700 \\
\hline S3J & $31^{\circ} 13^{\prime} 36.7$ & $30^{\circ} 10^{\prime} 51.9$ & 1.00 & 28.5 & 8.46 & - & - & 1.5 & 84.25 & 36.89 & 0.425 \\
\hline S3D & $31^{\circ} 13^{\prime} 36.7$ & $30^{\circ} 10^{\prime} 51.9$ & 0.65 & 16.3 & 8.18 & 12.51 & 16.8 & 0.3 & 98.29 & 49.54 & 0.338 \\
\hline S4J & $31^{\circ} 13^{\prime} 54.4$ & $30^{\circ} 11^{\prime} 24.3$ & 1.00 & 26.8 & 7.70 & - & - & 1.7 & 141.69 & 30.43 & 0.738 \\
\hline S4D & $31^{\circ} 13^{\prime} 54.4$ & $30^{\circ} 11^{\prime} 24.3$ & 0.78 & 15.9 & 8.49 & 10.16 & 32.0 & 0.2 & 91.90 & 19.79 & 1.175 \\
\hline S5J & $31^{\circ} 14^{\prime} 39.6$ & $30^{\circ} 13^{\prime} 23.3$ & 1.48 & 27.7 & 8.47 & - & - & 1.2 & 131.46 & 37.43 & 0.000 \\
\hline S5D & $31^{\circ} 14^{\prime} 39.6$ & $30^{\circ} 13^{\prime} 23.3$ & 0.63 & 15.3 & 7.92 & 9.95 & 18.5 & 0.2 & 76.58 & 53.73 & 0.700 \\
\hline S6J & $31^{\circ} 15^{\prime} 23.5$ & $30^{\circ} 13^{\prime} 58.7$ & 1.15 & 27.3 & 8.04 & - & - & 0.9 & 80.41 & 96.79 & 0.000 \\
\hline S6D & $31^{\circ} 15^{\prime} 23.5$ & $30^{\circ} 13^{\prime} 58.7$ & 0.54 & 17.1 & 7.52 & 4.22 & 16.5 & 0.2 & 97.00 & 71.61 & 0.125 \\
\hline S7J & $31^{\circ} 15^{\prime} 56.1$ & $30^{\circ} 13^{\prime} 35.1$ & 0.95 & 29.2 & 7.74 & - & - & 0.8 & 85.53 & 44.83 & 0.000 \\
\hline S7D & $31^{\circ} 15^{\prime} 56.1$ & $30^{\circ} 13^{\prime} 35.1$ & 0.72 & 17.3 & 7.90 & 7.78 & 56.5 & 0.2 & 82.96 & 46.59 & 0.038 \\
\hline S8J & $31^{\circ} 15^{\prime} 17.5$ & $30^{\circ} 14^{\prime} 19.5$ & 1.50 & 28.7 & 7.96 & - & - & 1.1 & 109.78 & 49.26 & 0.000 \\
\hline S8D & $31^{\circ} 15^{\prime} 17.5$ & $30^{\circ} 14^{\prime} 19.5$ & 0.26 & 16.5 & 7.33 & 2.51 & 15.5 & 0.1 & 91.90 & 68.25 & 0.000 \\
\hline S9J & $31^{\circ} 15^{\prime} 33.4$ & $30^{\circ} 12^{\prime} 22.9$ & 1.23 & 27.3 & 8.77 & - & - & 0.9 & 76.59 & 29.35 & 0.000 \\
\hline S9D & $31^{\circ} 15^{\prime} 33.4$ & $30^{\circ} 12^{\prime} 22.9$ & 1.97 & 16.3 & 8.29 & 8.11 & 86.5 & 0.2 & 61.28 & 8.75 & 0.000 \\
\hline S10J & $31^{\circ} 15^{\prime} 14.6$ & $30^{\circ} 12^{\prime} 24.7$ & 1.30 & 26.8 & 8.76 & - & - & 1.1 & 88.08 & 46.31 & 0.000 \\
\hline S10D & $31^{\circ} 15^{\prime} 14.6$ & $30^{\circ} 12^{\prime} 24.7$ & 1.17 & 16.5 & 8.14 & 6.96 & 72.5 & 0.2 & 91.90 & 0.00 & 0.213 \\
\hline S11J & $31^{\circ} 16^{\prime} 01.7$ & $30^{\circ} 10^{\prime} 47.9$ & 2.50 & 28.8 & 8.82 & - & - & 4.5 & 99.55 & 3.24 & 0.000 \\
\hline S11D & $31^{\circ} 16^{\prime} 01.7$ & $30^{\circ} 10^{\prime} 47.9$ & 3.32 & 17.9 & 8.03 & 6.06 & 71.5 & 0.9 & 84.25 & 16.29 & 0.125 \\
\hline
\end{tabular}

\section{Heavy metal content in surface sediment}

Lead $(\mathrm{Pb})$ has the highest values of the studied metals at all stations. Station 4 (Barsik Drain) has the highest $\mathrm{Pb}$ concentrations especially in June. It ranges from $61.28 \mu \mathrm{g} / \mathrm{g}$ in the central part at S9D to $141.69 \mu \mathrm{g} / \mathrm{g}$ at S4J (Barsik Drain) in the western part. Station 9, S10, followed by S11 have lower Pb values in both seasons compared to the other stations. $\mathrm{Pb}$ has higher concentration values in June at most of the stations (Table 1).

Copper $(\mathrm{Cu})$ has the highest value at S6 in both seasons $(96.79 \mu \mathrm{g} / \mathrm{g}$ in June and $71.61 \mu \mathrm{g} / \mathrm{g}$ in December), followed by S8 (El-Khairy Drain) especially in December $(68.25 \mu \mathrm{g} / \mathrm{g})$. Station 11 has the lowest detectable value $(3.24 \mu \mathrm{g} / \mathrm{g}$ in June and 16.29 $\mu \mathrm{g} / \mathrm{g}$ in December) followed by $\mathrm{S} 9$ especially in December $(8.75 \mu \mathrm{g} / \mathrm{g})$. It has undetectable limit at S10 in December. It has higher values in June compared to December at the most of stations (Table 1). 
Cadmium (Cd) exhibits the lowest level of the studied metals in Lake Edku sediments; it reaches to nearly zero value at some stations, while it shows a maximum of $1.175 \mu \mathrm{g} / \mathrm{g}$ at $\mathrm{S} 4$ (Barsik Drain) in December and $0.738 \mu \mathrm{g} / \mathrm{g}$ in June. Cadmium (Cd) has more recognizable values in December compared to June (Table 1).

According to U.S. Environmental Protection Agency (U.S. EPA, 1999) and Environmental Canadian Standards (2002), Lake Edku sediments exceed the permissible limits of $\mathrm{Pb}, \mathrm{Cu}$ and $\mathrm{Cd}$ in several stations (Table 2).

Table 2. Permissible limits of Heavy metals $(\mu \mathrm{g} / \mathrm{g})$. Abbreviations: U.S. EPA: U.S. Environmental Protection Agency; C-EQG: Canadian Environmental Quality Guidelines; PEL: Probable Effect Level; ISQG: Interim Sediment Quality Guideline

\begin{tabular}{|c|c|c|c|c|}
\hline Metal & U.S. EPA & \multicolumn{2}{|c|}{ C-EQG } & Present study \\
\hline & & & ISQG & \\
\hline $\mathrm{Pb}$ & 31 & 91.3 & 33 & $61.28-141.69$ \\
\hline $\mathrm{Cu}$ & 16 & 197 & 35.7 & $0-96.79$ \\
\hline $\mathrm{Cd}$ & 0.6 & 3.5 & 0.6 & $0-1.175$ \\
\hline
\end{tabular}

\section{Benthic Foraminiferal Assemblage}

Rotaliina is the most dominant suborder; representing $89.9 \%$ of the total foraminiferal assemblage. Textulariina is the second most dominant suborder; representing $7.1 \%$ of the total foraminiferal assemblage. Miliolina, representing $2.92 \%$ of the total foraminiferal assemblage, is in the third order and about $0.08 \%$ representing different other suborders, unknown species and/or fragments. Rotaliina has the highest abundance values in almost all stations except at S4J. It decreases significantly at Boughaz El-Meadia. Textulariina was observed only at S4J (96\%), S7D (39\%) and S8j (2.4\%). Miliolina abundance was low at almost all stations and it increases towards Lake-Sea connection especially at S11 (Boughaz El-Meadia) (Fig. 2). Among 38 recorded species belonging to 20 genera; 15 species showing relative abundance greater than $2 \%$ in at least one sample. Ammonia tepida is the most dominant taxon representing $51.5 \%$ of the total foraminiferal assemblage. It is followed by Ammonia Parkinsoniana representing (32.1\%), Saccorhiza ramosa (7.14\%), and Porosononion spp. (2.5\%).

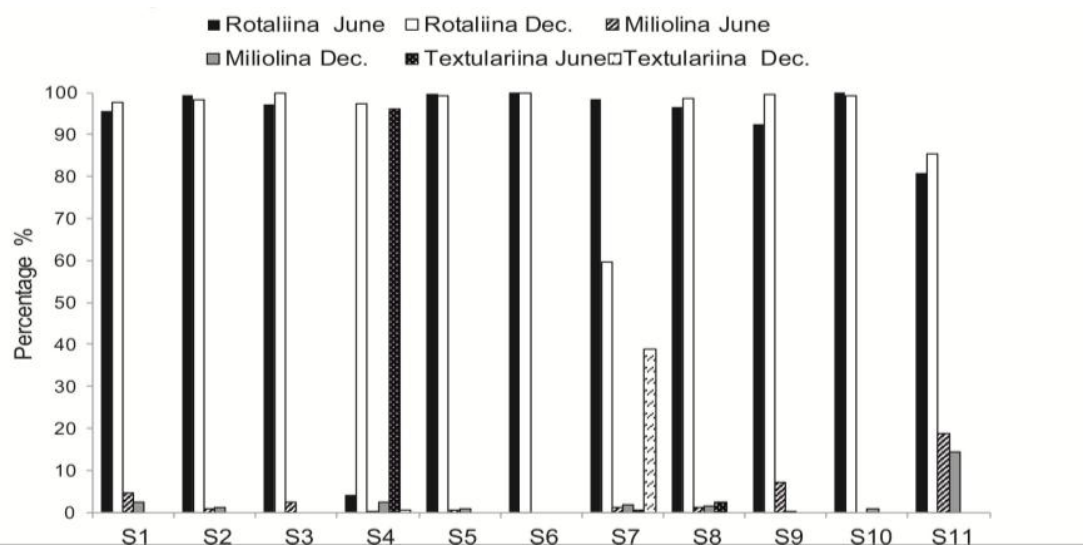

Fig. 2: Distribution pattern of the major foraminiferal suborders in Lake Edku.

Ammonia tepida, the most dominant taxon, decreases towards Boughaz ElMeadia which connects Lake Edku with the Mediterranean Sea. It has lower values at $\mathrm{S} 9, \mathrm{~S} 10$ and S11 in both seasons and at S4J. Concerning the seasonal distribution, $A$. 
tepida has high relative abundances in winter season (Fig. 3a). Ammonia parkinsoniana, the second most dominant species, has its highest values at S10 (74.6\% in June and $54.2 \%$ in December) and $S 9(60.7 \%$ in June and $42.8 \%$ in December). Its distribution is higher in June than December (Fig. 3b). Saccorhiza ramose, the third dominant species, has its maximal distribution (96\%) at S4J (Barsik Drain). It was recorded sporadically in two other stations S7D and S8J (El-Khairy Drain) with lower percentage $39 \%$ and $2.4 \%$ respectively. It has very low percentage $(0.4 \%)$ at S4D (Fig. 3c). Porosononion spp., the fourth dominant species, has its highest abundance at S2D (7.9\%) and S1D (7.6\%) (Fig. 3d). Quinqueloculina lata, the fifth dominant species, has its highest values at S11J (8.9\%) and S9J (4.7\%). Its distribution is higher in June than in December with some exceptions (Fig. 3e).
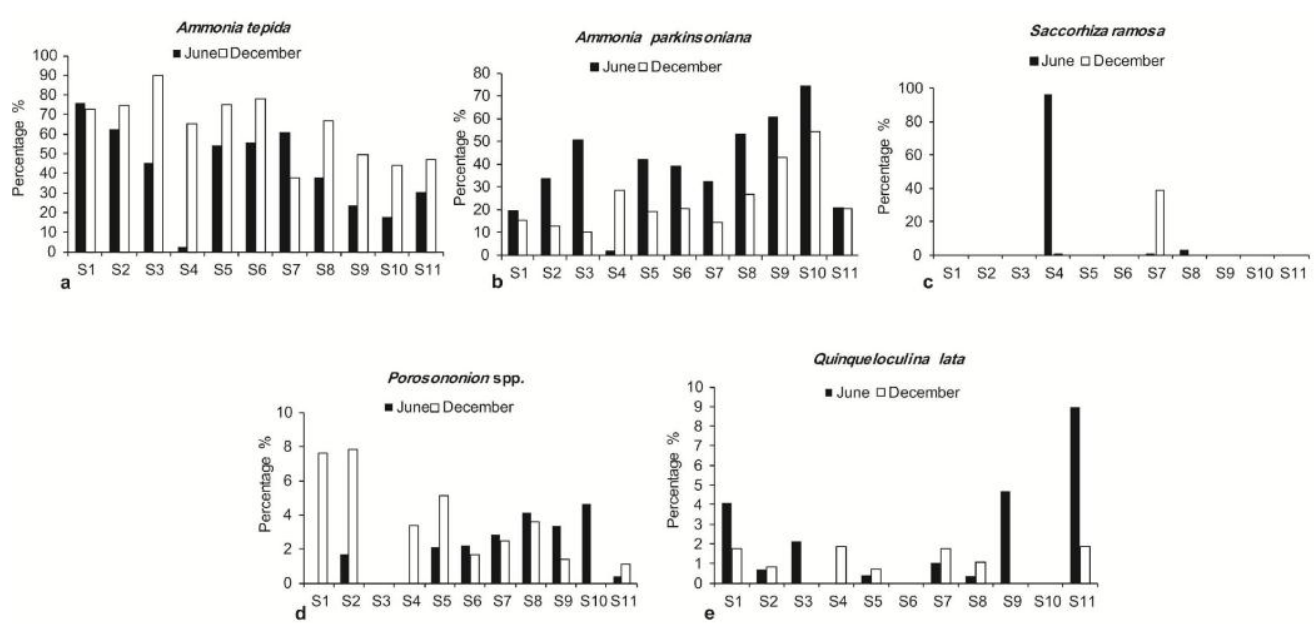

Fig. 3: Distribution pattern of the five most-dominant foraminiferal species expressed as relative abundance.

\section{Dead benthic foraminifera}

The distribution trend of living foraminifera is low in almost all stations of Lake Edku. Living foraminiferal percentage are higher in June than in December. Non-living foraminifera has higher percentage especially in December. The highest percentages of living foraminifera were found at S10J representing $53.76 \%$ and S8J representing $42.76 \%$, while the highest percentages of non-living foraminifera were found at S4J (Barsik Drain) representing 100\% and S8D (El-Khairy Drain) representing $95.34 \%$ (Fig. 4).

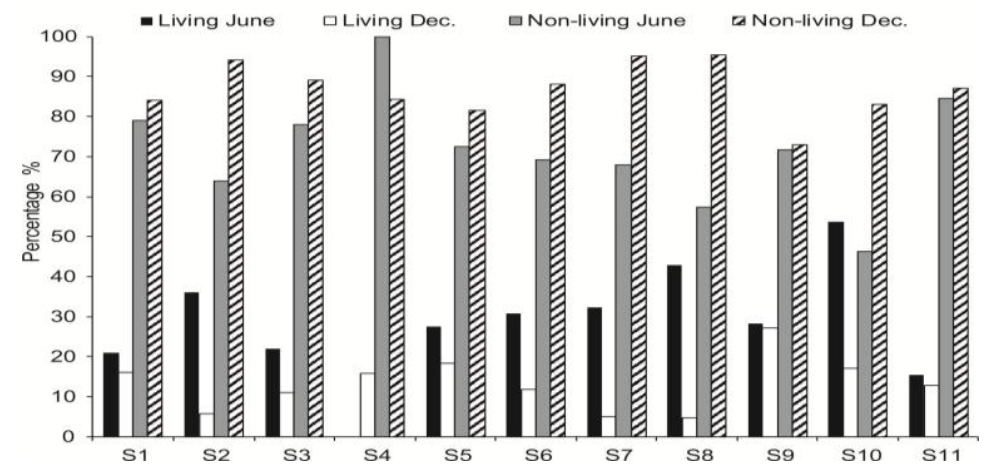

Fig. 4: Distribution pattern of living and non-living foraminifera in the investigated samples.

\section{Foraminiferal density and diversity}

Concerning the total foraminiferal assemblage, foraminiferal density (number of individuals per $50 \mathrm{~cm}^{3}$ of sediment) is highly variable at spatial scale ranging from 
64 individuals per $50 \mathrm{~cm}^{3}$ at S6D to 152228.6 individuals per $50 \mathrm{~cm}^{3}$ at $\mathrm{S} 10 \mathrm{D}$. It has two outstanding peaks at S10D and S9J (152228.6 and 140169.6 individuals per 50 $\mathrm{cm}^{3}$ respectively) (Table 3 ).

Table 3: Density, diversity indices and percentage of deformed species in the investigated stations of Lake Edku.

\begin{tabular}{cccccccccc}
\hline Station & S & Individuals & Dominance & Shannon & Simpson & Fisher's & Density & Deformed \\
\hline S1J & 4 & 292 & 0.618 & 0.678 & 0.382 & 0.656 & 17528.6 & 9.2 \\
\hline S1D & 10 & 288 & 0.561 & 0.917 & 0.439 & 2.012 & 10600.0 & 15.6 \\
\hline S2J & 6 & 294 & 0.506 & 0.829 & 0.495 & 1.067 & 1350.2 & 12.2 \\
\hline S2D & 11 & 242 & 0.582 & 0.910 & 0.418 & 2.374 & 1200.0 & 19.0 \\
\hline S3J & 7 & 281 & 0.463 & 0.881 & 0.537 & 1.301 & 26250.0 & 16.7 \\
\hline S3D & 2 & 276 & 0.818 & 0.328 & 0.182 & 0.292 & 8528.6 & 10.9 \\
\hline S4J & 4 & 300 & 0.916 & 0.217 & 0.084 & 0.652 & 4446.4 & 3.0 \\
\hline S4D & 7 & 267 & 0.507 & 0.888 & 0.493 & 1.316 & 1500.0 & 17.2 \\
\hline S5J & 5 & 237 & 0.475 & 0.840 & 0.525 & 0.896 & 6037.5 & 8.9 \\
\hline S5D & 4 & 136 & 0.602 & 0.721 & 0.398 & 0.773 & 74.5 & 20.6 \\
\hline S6J & 6 & 136 & 0.465 & 0.911 & 0.535 & 1.284 & 71.5 & 20.6 \\
\hline S6D & 3 & 118 & 0.650 & 0.587 & 0.351 & 0.560 & 64.0 & 17.8 \\
\hline S7J & 12 & 283 & 0.478 & 0.974 & 0.522 & 2.541 & 1753.8 & 10.6 \\
\hline S7D & 12 & 284 & 0.314 & 1.415 & 0.686 & 2.539 & 1101.7 & 7.0 \\
\hline S8J & 10 & 290 & 0.428 & 1.058 & 0.572 & 2.008 & 352.2 & 9.3 \\
\hline S8D & 7 & 279 & 0.523 & 0.865 & 0.477 & 1.303 & 1114.3 & 7.2 \\
\hline S9J & 19 & 298 & 0.428 & 1.300 & 0.572 & 4.520 & 140169.6 & 13.5 \\
\hline S9D & 9 & 292 & 0.431 & 1.031 & 0.569 & 1.758 & 24725.7 & 9.2 \\
\hline S10J & 8 & 279 & 0.589 & 0.824 & 0.411 & 1.536 & 26062.5 & 10.8 \\
\hline S10D & 7 & 295 & 0.488 & 0.789 & 0.512 & 1.287 & 152228.6 & 5.1 \\
\hline S11J & 28 & 245 & 0.158 & 2.393 & 0.842 & 8.149 & 35863.6 & 11.0 \\
\hline S11D & 18 & 273 & 0.275 & 1.841 & 0.726 & 4.326 & 18573.5 & 9.9 \\
\hline & & & & & & & & \\
\hline
\end{tabular}

Regardless of these two peaks, foraminiferal density increases toward seaward direction at S9, S10, S11 in both seasons and decreases in stations near to the discharge such as S6, S8 (El-Khairy Drain), S4 (Barsik Drain) and S5 in both seasons. S6 is considered as very poor station in both seasons, followed by S5 in December. In addition, Total foraminiferal density shows clear seasonal trend; since foraminiferal density is generally higher in June compared to December (Table 3).

Species diversity refers to the number of taxa in an assemblage, while dominance is expressed as a percentage of the population, and lower dominance tends to be found with higher diversity (Armstrong and Brasier, 2005). Concerning the total foraminiferal assemblage, the foraminiferal diversity is low in the investigated stations and increases towards the sea connection near Boughaz El-Meadia. For example, Shannon diversity $\mathrm{H}$ has low values with a range of 0.217 to 1.841 with the exception of S11 which reaches to 2.393. Station11 in both seasons, S7D and S9J have the highest different diversity indices values, while S4J, S3D and S6D have the lowest values (Table 3). The opposite trend was recorded for the dominance; since the most seaward station (S11) has the lowest dominance in both seasons (Table 3). No clear seasonal diversity pattern has been recorded. Few species numbers are recorded in the study area. It ranges from 2 to 19 with the exception of S11 at Boughaz ElMeadia; since it reaches to 28 (Table 3). 


\section{Test deformation}

In this study, the percentage of deformed tests are relatively high (up to $\sim 21 \%$ of the total foraminiferal assemblage). There are ten modes of deformation including: lose milioline coiling (Fig. 5.1), not rounded periphery (Fig. 5.2-5), protruding in last chamber (Fig. 5.6-8), abnormal additional chamber (s) (Fig. 5.9-10), distortion in coiling (Fig. 5.10), Siamese twins (Fig. 5.11, 12), abnormal growth (Fig. 5.13-17), division in last chamber (Fig. 5.18), spiroconvex shape (Fig. 5.19), and highly deformed specimens (Fig. 5.20). The distribution of deformed specimens was decreasing towards the Lake-Sea connection at S9, S10 and S11. In contrast, higher deformation percentages are present at S1, S2, S3, S4, S5, S6 and S7 with few exceptions. The highest percentages of deformed foraminifera were found at S6J and S5D $(20.58 \%)$ while the lowest percentage of deformed foraminifera were found at S4J (3\%) and S10D (5.08\%) (Table 3). The highest deformation percentage was recorded in Rotaliina (11.24\%). Ammonia tepida is the highest deformed species in Rotaliina suborder (7.5\%), followed by A. parkinsoniana $(3.48 \%)$ and Porosononion spp. (0.12\%). Miliolina showed very low deformation percentage $(0.1 \%)$. Only $Q$. lata and Quinqueloculina spp. were deformed. Textulariina shows no deformation.

\section{Redundancy analysis (RDA)}

The length of the first gradient of DCA indicates the linear character of the dataset, that's why RDA has been processed. The first RDA axis represents $34.8 \%$ of the total variance, while the second RDA axis represents $24.1 \%$ of the variance. From the statistical analysis four groups with comparable distribution patterns can be recognized. Group 1 composes of one species, S. ramosa. This species indicates a close positive relation to $\mathrm{Pb}, \mathrm{Cd}$ concentrations and to a lesser extent with temperature, water depth and salinity, while it indicates a negative correlation with $\mathrm{pH}$ and moderate negative correlation with $\mathrm{Cu}$ content and $\mathrm{DO}(\mathrm{Pb}-\mathrm{Cd}$ tolerant species). Group 2 is dominated mainly by A. tepida followed by Porosononion spp. They are ordinated at positive part of the $\mathrm{Cu}$, DO gradient and at the negative part of $\mathrm{Pb}$, temperature, depth and salinity. Ammonia tepida shows a similar correlation as Porosononion spp., but with different gradient length. Additionally A. tepida shows a moderate positive correlation with $\mathrm{Cd}$, while Porosononion spp. shows a moderate negative correlation with $\mathrm{Cd}(\mathrm{Cu}$ and/or Cd tolerant, $\mathrm{Pb}$ sensitive species). Group 3 is dominated by $A$. parkinsoniana. This species is related to higher temperature, $\mathrm{pH}$, water depth, while it related to lower $\mathrm{Pb}, \mathrm{Cd}$ and $\mathrm{Cu}$ content and $\mathrm{DO}$ (heavy metals sensitive species). Group 4 is dominated by the rest of species which is ordinated in the center of graph (Fig. 6).

\section{Cluster analysis}

R-mode cluster analysis groups the species into two main clusters, (A, B). Two distinct sub-clusters (A1 and A2) can be recognized within cluster A. Sub-cluster A1 is composed of $S$. ramosa. Sub-cluster A2 is divided into A2I and A2II. A2I is composed of $A$. parkinsoniana (sensitive species) and it is distinguished from the rest of the species (A2II). Cluster B is composed of the tolerant species such as A. tepida and Porosononion spp. (Fig. 7). Q-mode cluster analysis is succeeded in separating S11D (Boughaz El-Meadia), the less polluted station, in cluster A. The rest of the stations are grouped in cluster B. Station $4 \mathrm{~J}$, which is dominated by S. ramose, is distinguished in sub-cluster B1. The rest of stations are located in sub-cluster B2 (Fig. 8). 


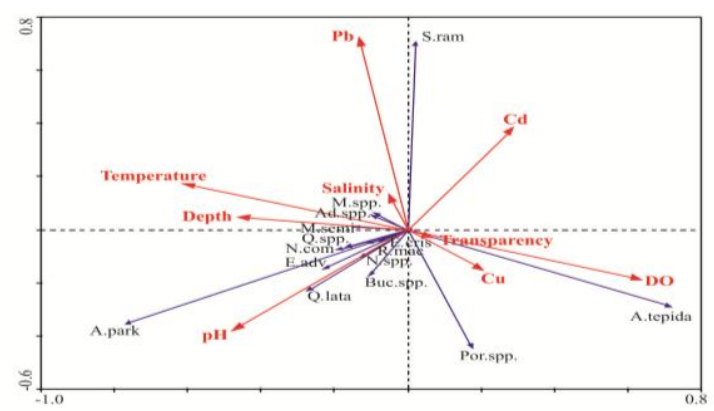

Fig. 6. Redundancy Analysis (RDA) for all surface samples showing species-environment relationships. Abbreviations: Ad.spp.: Adelosina spp., A.park: Ammonia parkinsoniana (d'Orbigny, 1839), A.tepida: Ammonia tepida (Cushman, 1926), Buc.spp.: Buccella spp., E.adv: Elphidium advenum (Cushman, 1922), E.cris: Elphidium crispum (Linnaeus, 1758), M.semi: Miliolinella semicostata (Wiesner, 1923), M.spp.: Miliolinella spp., N.com: Nonion commune (Kassel, 1963), N.spp.: Nonion spp., Por.spp.: Porosononion spp., Q.lata: Quinqueloculina lata (Terquem, 1876), Q.spp.: Quinqueloculina spp., R.mac: Rosalina macropora (Hofker, 1951), S.ram: Sacchoriza ramosa (Brady, 1879).

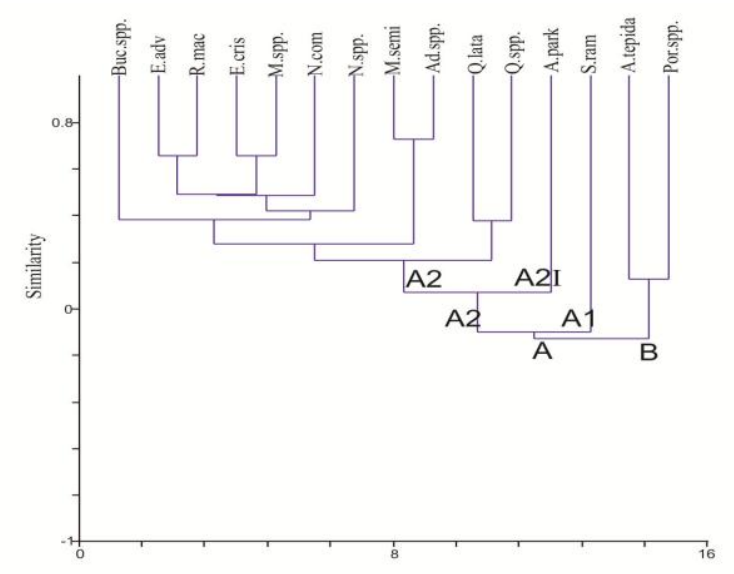

Fig. 7. Dendogram produced by R-mode cluster analysis using Rho Correlation Spearman's for the investigated species. Species abbreviations are listed in Figure 12.

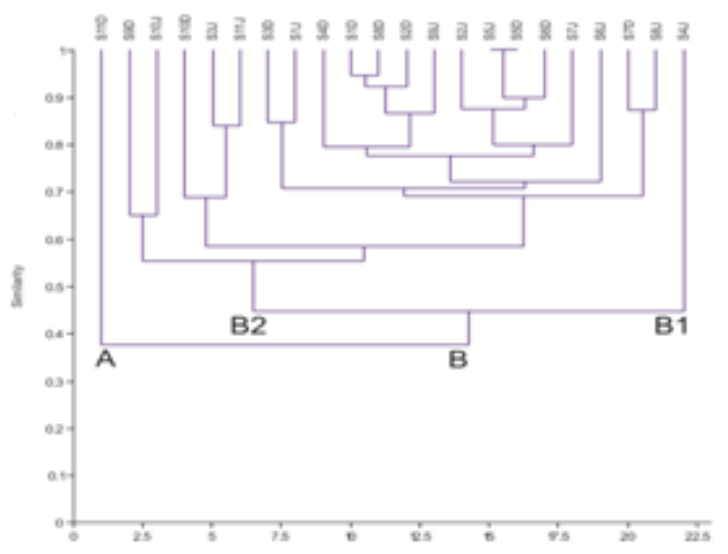

Fig. 8: Dendogram produced by Q-mode cluster analysis using Rho Correlation Spearman's for sediments of the investigated stations. 


\section{DISCUSSION}

\section{Variability of environmental parameters in the study area}

High values of $\mathrm{Pb}, \mathrm{Cu}$ and $\mathrm{Cd}$ were recorded in the sediment of Lake Edku. The most of these values exceed the permissible limits according to U.S. EPA (1999) and Environmental Canadian standards (2002). Some previous studies in Lake Edku recorded lower values of heavy metals compared to the present study (Masoud et al., 2005; Gu et al., 2013; Abdalla and Morsy, 2013; El-Said et al., 2014), while other previous studies reported lower values of $\mathrm{Pb}$ and $\mathrm{Cu}$ but higher values of $\mathrm{Cd}$ (AbdelMoati and El-Sammak, 1997; El Zokm et al., 2015) (Table 4). This could be related to the increased pollution levels in the lake as a result of accumulated continuous discharge.

Table 4: Comparison between the heavy metal data $(\mu \mathrm{g} / \mathrm{g})$ observed in the present study and the previous heavy metal data in Lake Edku $(\mu \mathrm{g} / \mathrm{g}$.)

\begin{tabular}{llll}
\hline \multicolumn{1}{c}{$\mathbf{P b}$} & \multicolumn{1}{c}{$\mathbf{C u}$} & \multicolumn{1}{c}{$\mathbf{C d}$} & \multicolumn{1}{c}{ References } \\
\hline $\mathbf{6 1 . 2 8}-\mathbf{1 4 1 . 6 9}$ & $0-96.79$ & $0-1.175$ & Present study \\
\hline $\mathbf{2 0}$ & 19 & 7.30 & Abdel-Moati and El-Sammak (1997) \\
\hline $\mathbf{1 . 1 5}-\mathbf{2 . 4 1}$ & $1.83-2.57$ & $0.62-1.56$ & Masoud et al. $(2005)$ \\
\hline $\mathbf{2 . 4 \pm 0 . 6}$ & $2.2 \pm 0.4$ & $1.1 \pm 0.5$ & Abdalla and Morsy (2013) \\
\hline $\mathbf{1 5}$ & 62 & 1.19 & Gu et al. $(2013)$ \\
\hline $\mathbf{0 . 7 8 3 - 8 1 . 0 7 9}$ & 62.26 & - & El-Said et al. $(2014)$ \\
\hline
\end{tabular}

These metals distribute in Lake Edku as a result of anthropogenic activities; The use of $\mathrm{CuSO}_{4}$ as an algicide in treating and controlling the massive macroalgal blooms in the Nile, especially during summer, which makes navigation nearly impossible, is the main source of $\mathrm{Cu}$ to the Nile water, streams and drains and its transfer through the drainage water to the Nile delta lakes (Abdel-Moati and ElSammak, 1997). El-Khairy and Barsik Drains are the major sources of pollution in Lake Edku. They transport huge amounts of mostly agricultural drainage enriched with $\mathrm{Cd}$ as by-products of fertilizers and $\mathrm{Cu}$ which used in the manufacturing of fertilizers and algicide (Sanita di Toppi and Gabbrielli, 1999; Badr and Fawzy, 2008). Therfore we focused in the current study on the analysis of $\mathrm{Pb}, \mathrm{Cu}$ and $\mathrm{Cd}$. Metal concentrations in sediments of Lake Edku varies spatially and temporally. Spatial variations of trace metals in sediments are likely caused by discharges of sewage, industrial activities, and surface runoff along the coastal areas (Tang et al., 2008). The distribution and accumulation of heavy metals are influenced by complex factors, such as sediment composition and structure, grain-size, and the hydrodynamic conditions (Christophoridis et al., 2009; Qiao et al., 2013). Due to these multiple factors, heavy metal concentrations in sediment change spatially and temporally (Liu et al., 2011). El-Said et al. (2014) revealed that the variation of heavy metal concentrations in Lake Edku was reliant on lithology and anthropogenic activities sources.

The current water depth data indicate that it is a shallow lake; the water depth is low especially in December, but it increases towards Lake-Sea connection which is in agreement with Shakweer (2006) and Badr and Fawzy (2008). Lake Edku shows low salinity with a range of $0.1 \%$ to $5.5 \%$. The low salinity recorded for Lake Edku indicates the discharge of drainage water from agricultural lands surrounding the lake (Badr and Fawzy, 2008). The drainage water plays an important role in decreasing the 
salinity of the lake water (Shakweer, 2006(. Water temperature undergoes huge seasonal variations but it has narrow spatial variations in both seasons. Shakweer (2006) revealed that the shallow Lake Edku follow water temperature variations parallel to those of air temperature. The shallowness of these lake as well as the effect of blowing winds contribute in mixing the whole water body. Therefore variations in water temperature between surface and bottom water lie in a narrow range. The $\mathrm{pH}$ data show that the water of Lake Edku is slightly alkaline which is in agreement with Badr and Fawzy (2008) and Abdalla and Morsy (2013). They attributed the elevation of $\mathrm{pH}$ to the relative abundance of aquatic plants in the lake which increases the rate of photosynthesis which in turn causes an increase in the $\mathrm{CO}_{2}$ consumption and hence increase in $\mathrm{pH}$ values. Lake Edku is an oxygenated lagoon which is in agreement with Shakweer (2006) and Badr and Fawzy (2008). On the other hand, Abdallah and Morsy (2013) recorded lower values of DO. It is a matter of fact that in shallow water bodies the dissolved oxygen is greatly affected by air and water temperatures, wind mixing and photosynthetic activity. The oxidation processes in water and sediments can be also considered as an important factor controlling the dissolved oxygen in water. The importance of dissolved oxygen for aquatic plants and animals is directly related to the respiration process or indirectly with the oxidation of organic matter in water and sediments (Shakweer, 2006). The Water transparency of Lake Edku increases toward the sea at S9, S10 and S11 as the depth increases. Due to the shallowness of Lake Edku, the seasonal variation of wind directions and duration affects greatly the transparency of this lake (Shakweer, 2006). Shakweer (2006) observed also that the sechi depth reached its minimum value during spring and this can be attributed to the maximum flourishment of phytoplankton which plays an effective role in decreasing the visibility in the shallow lake water. The stagnancy of the water during summer and autumn decreases the turbidity in the whole area of the lake and therefore higher sechi depths were recorded during these two seasons in comparison with winter where the wind actions increase the turbidity of the water especially in the shallower water of the eastern basin.

\section{Foraminiferal species density and diversity}

Higher foraminiferal density values were recorded in the seaward direction. In the current polluted study area foraminiferal diversity is generally low with the exception of seaward stations. The decreased species diversity and density in polluted stations of Lake Edku is in agreement with Samir and El-Din. (2001), Armynot du Châtelet et al. (2004), Bergin et al. (2006) and Li et al. (2014) who concluded that density and species diversity of the assemblages decrease with an increase in heavy metal concentration and may be used as pollution indicators. Banerji (1992) recorded that species diversity is less in sediments with $\mathrm{Co}-\mathrm{Ni}-\mathrm{Pb}$. Jayaraju and Reddy (1996) proved that pollution from industrial effluent causes reduced diversity and population. Nigam et al. (2002) reported decline in total foraminiferal number and species diversity as a result of increased suspended load from mining activities. Martins et al. (2010) reported that higher total available concentrations of $\mathrm{As}, \mathrm{Cd}, \mathrm{Cu}$, $\mathrm{Ni}, \mathrm{Pb}$ and $\mathrm{Zn}$ have an adverse effect on the living assemblages of benthic foraminifera inducing not only low diversity but also higher dominance. Benthic foraminifera respond negatively at the site of high intensity of pollution (Naidu et al., 2000). Armynot du Châtelet et al. (2011) also concluded that the concentration of heavy metals $(\mathrm{Cr}, \mathrm{Cu}$ and $\mathrm{Zn}$ ) had a strong negative impact on species richness patterns in benthic foraminifera. A reduction in species diversity and specimen density was probably induced by increasing pollution (Cherchi et al., 2009). Ferraro et al. (2006) observed a reductions in foraminiferal density and species richness were 
revealed as a response to an increase in trace element pollution. In particular, they documented a completely barren area which corresponded to the greatest concentrations of trace elements $(\mathrm{Pb}, \mathrm{Hg}, \mathrm{Ni}$ and $\mathrm{Zn})$ from two to nine times higher than at the other stations. In the current work, S6 could be considered more or less as a barren area. This poor foraminiferal density could be related to high $\mathrm{Cu}$ value. On the other hand, some previous studies showed that population density of foraminifera may increase in vicinity of sewage outfalls (Watkins, 1961; Nikulina et al., 2008). Alve (1995) stated that the increased abundances have been reported from areas that receive effluents primarily from pulp and paper industries.

In the current study, the dominance of few species was recorded. Since $A$. tepida and A. parkinsoniana are representing $83.6 \%$ of the total community, and together with $S$. ramose are representing $90.7 \%$ of the total community. This may indicate the stressful condition of Lake Edku. Cognetti (1992) reported that the dominance of a low number of species indicates environmental stress. On the other hand, Alve (1995) showed that the high abundance of one species in an area affected by a particular effluent does not necessarily imply that it is the most tolerant species. However, it can be the most successful opportunist, with a rapid turnover rate and the ability to quickly colonize a disturbed area almost independent of the type of contaminant.

Comparing current foraminiferal diversity with previous foraminiferal diversity study in Lake Edku in 2000, we found a remarkable decrease in the diversity. Samir (2000) reported higher species number (9-23) and higher Shannon H values of (1.461.82) in Lake Edku. This is may be related to the continuous increased discharge in the lake.

Density and diversity of foraminifera increases towards the sea connection. The highest diversity was observed at S11 (Boughaz El-Meadia), which may be attributed to high salinity, increasing water depth and/or grain size in addition to its far away position from pollution sources. This salinity effect is in agreement with Martins et al. (2013) who reported that salinity has significant positive correlation with foraminiferal density and diversity. Foraminiferal density and diversity reach higher values near the lagoon mouth under higher marine influence. Increasing water depth at $\mathrm{S} 11$ could attribute to the increasing foraminiferal density and diversity in this station. According to Buzas et al. (2007), foraminiferal abundance and species diversity increase with depth. Sediments structure is the most important factor affecting density and diversity of benthic foraminifera (Armynot du Châtelet et al., 2009). Khalil et al. (2013) revealed that the sediments collected from Lake Edku composed of a mixture of sand silt and clay; the Lake-Sea connection has sand rich sediments derived from the Mediterranean Sea and marine sediment. The eastern basin rich with silt and clay sediments which transported by the drains. The sediment of Barzik drain is rich with sand fraction, while El-Khairy drain is rich with silt and clay sediments. The increasing foraminiferal density and diversity in the sandy station of S11 is in disagreement with Armynot du Châtelet et al. (2009) and Sadough et al. (2013). They reported that the relatively fine grain-size is associated with a high foraminiferal density and richness.

\section{Living $v s$. dead foraminifera and the effect of seasonality}

In the current study, the total foraminiferal density and the percentage of living foraminifera have the same increasing pattern in summer, which could be related to increased temperature rather than to pollution. Morvan et al. (2006) showed that temperature may act directly on the biology of foraminifera, or, indirectly, by increasing their food supply (microflora). Reproduction periods have often been 
considered as a response to the increase in food supply resulting from phytoplankton blooms (e.g., Walton, 1955; Alve and Murray, 1994). Shakweer (2006) reported that maximum flourishment of phytoplankton in Lake Edku occurs during summer. Hence, the increase of density and living foraminifera in summer may be attributed to the increase of phytoplankton. Serandrei Barbero et al. (2003) studied the temporal changes in benthic foraminiferal assemblages. They pointed out that the main controlling factor of the productivity of benthic foraminifera is the occasional availability of phytoplankton. The life cycle of shallow-water benthic foraminiferal species may be strongly influenced by seasonality (Murray, 1991). Buzas (1965) observed that the total number of live individuals was greatest in the summer when maximum water temperature and highest abundance of zooplankton and phytoplankton occurred along U.S. Atlantic coast. Nikulina et al. (2008) observed that foraminiferal population density showed a patchy distribution and a response to food availability, which is depicted by $\mathrm{SiO}_{2}$ and Chl- $a$ in the sediments. They noticed a positive correlations of population density with biogenic silica and chlorophyll- $a$. On the other hand, Murray and Alve (2000) did not notice any correlation between the size of the standing crop and the chlorophyll $a$ content of the surface sediment at either station of the Hamble Estuary.

Reproduction occurs annually, but not all species reproduce at the same time. Changes in density are directly related to reproduction patterns (Debenay, 2009). Many studies suggested that reproduction peaks, responsible for higher densities, occur once or a few times a year, but other studies pointed out that foraminiferal assemblages are not always affected by year cycles. Even if maximum standing crop often occurs at some particular time of the year, continuous or nearly continuous reproduction throughout the year is a commonplace (Buzas et al., 2002; Morvan et al., 2006). In the present work, we will not discuss in detail the seasonal reproduction pattern for each species; since the percentage of living fauna is very small compared to non-living one. This low living foraminiferal percentage may be related to the increased pollution level in the study area. In addition, better understanding of the seasonal variations could be made through sampling in additional seasons and years. Milker et al. (2015) demonstrated that seasonal variability has an insignificant influence on the distribution of live species in the intertidal environments of Bandon Marsh, Oregon, USA. They collected samples in summer and fall of two successive years. They attributed this to precipitation as it influences the pore water salinity in salt marshes.

Higher numbers of dead foraminifera were found at El-Khairy and Barsik drains which prove the detrimental effects of pollution on the foraminiferal assemblages. This is in agreement with Setty (1982), who reported that living foraminifers are absent in polluted areas. Cearreta et al. (2000) also reported that living foraminifera were absent from surface sediments in the upper Bilbao estuary (North Spain), and were not abundant in the middle and lower estuary, due to persistent anoxia in the estuarine channel, and possibly, high pollutant concentrations.

Closs and Madeira (1968) reported that reproduction periods of the abundant species are diverse and may change from one station to the other. Based on the same kind of observations, Buzas et al. (2002) proposed a model where individual foraminifers are spatially distributed as a heterogeneous continuum, forming patches with different densities that are only meters apart. Reproduction is a synchronous causing patches that vary in space and time. One station may exhibit seasonal periodicity while a nearby station may not (Morvan et al., 2006). The two extreme total foraminiferal density peaks at S9J and S10D may be interpreted by this 
foraminiferal patchy distribution.

In the present study no clear seasonal diversity trend was recorded, in spite of some previous studies recorded minimum values of foraminiferal species number and alpha index in the spring to early summer and maximum values in the autumn (Murray and Alve, 2000). Although in the present work foraminiferal assemblages doesn't reflect clear seasonal cycle, on a species level A. tepida has higher percentage in December than in June which in accordance with some previous studies. De Nooijer et al. (2008) noticed that A. tepida is abundant in winter than in summer months. Morvan et al. (2006) reported that A. tepida was one of the most dominant species at the mouth of a small river of the Atlantic coast of France and it had maximum density in December 2001. A sharp increase occurred in the standing crop during fall and winter 2001.

\section{Foraminiferal assemblages and environmental characterization}

The high relative abundance of $A$. tepida, the most dominant species, in the current polluted study area (up to $89.8 \%$ ) may indicate its tolerance to pollution. The dominance of $A$. tepida in other polluted coastal regions is confirmed by previous studies. For example Ferraro et al. (2006) found a relative abundance up to $100 \%$ in polluted Naples Harbour (Tyrrhenian Sea, Southern Italy). Burone et al. (2006) obtained a relative abundance up to $98 \%$ in the Montevideo coastal zone, Uruguay. Ammonia tepida has been reported as the dominant species in areas close to outfalls discharging sewage, heavy metals, chemical and thermal pollution, fertilizing products, caustic soda, chlorine complexes and hydrocarbons (Alve, 1991; 1995; Yanko et al.,1994; Samir, 2000; Samir and El Din, 2001; Armynot du Châteletet al., 2004; Vilella et al., 2004; Burone et al., 2006; Ferraro et al., 2006; Le Cadre and Debenay, 2006; Frontalini and Coccioni, 2008; Romano et al., 2008, 2009; Coccioni et al., 2009; Debenay and Fernandez, 2009; Armynot du Châtelet and Debenay, 2010; Frontalini et al., 2010, 2011; Elshanawany et al., 2011; Aloulou et al., 2012 and Martins et al., 2013).

Closer inspection to our data show that A. tepida correlated positively with $\mathrm{Cd}$ and $\mathrm{Cu}$, while negatively correlated with $\mathrm{Pb}$. Therefore this study confirms its tolerance to $\mathrm{Cd}$ and $\mathrm{Cu}$ pollution rather than to $\mathrm{Pb}$ pollution. Frontalini and Coccioni (2008) and Aloulou et al. (2012) showed that A. tepida has a significant positive correlation with Cd. Frontalini et al. (2010) observed that A. tepida is the most dominant species in two italian lagoons which had higher values of $\mathrm{Cd}, \mathrm{Cu}, \mathrm{Ni}, \mathrm{Pb}$, $\mathrm{Zn}, \mathrm{Hg}$ and As. Dimiza et al. (2016) showed that A. tepida was positively correlated with several heavy metal $(\mathrm{Cu}, \mathrm{Ni}, \mathrm{Pb}$ and $\mathrm{Zn})$ and metalloid (As) contents. On the other hand, Li et al. (2015) reported that A. tepida has a weak positive correlation with $(\mathrm{Cr}, \mathrm{Cu}, \mathrm{Ga}, \mathrm{Pb}, \mathrm{Rb}, \mathrm{Zn}$ and $\mathrm{Zr})$

Foraminiferal faunal community structure has been changed in Lake Edku in the last decade as a result of increased discharge. Samir (2000) reported that in Lake Edku, A. tepida showed lower abundance (7.6-22.6\%), in contrast to $A$. parkinsoniana, which showed a corresponding increase (39.7-62.5\%).

In the present study, Lake Edku has low salinity as a result of the increasing discharge of the drainage water (Shakweer, 2006; Badr and Fawzy, 2008). It is not surprising to find A. tepida dominates in this low saline Lake; since A. tepida is a cosmopolitan species occurring in brackish lagoons, estuaries and shallow marine areas that are extremely variable environments both temporally and spatially (Murray, 2006). Jorissen (1988) linked the dominance of A. tepida within the assemblages to its tolerance to polluted and low salinity environments. It is able to survive a wide range of temperature, salinity and other environmental parameters varying on 
seasonal or daily scales and to survive severe environmental conditions. (AlmogiLabin et al., 1992; Debenay et al., 2005; Munsel et al. 2010; Geslin et al., 2014). Almogi-Labin et al. (1992) reported that living populations of A. tepida are opportunistic, capable of withstanding a wide range of salinity (5-56\%) and different types of pollution. Martins et al. (2013) observed a negative correlation with salinity and A. tepida which dominate in lower saline waters.

Another environmental parameter could affect the distribution of A. tepida; which is the grain size. Although we have no grain size data, but from previous studies it is known that the sediment of the lake is silt and clay in the eastern part, shelly mud in the transition central part, and sand near Boughaz El-Meadia (Ibrahim, 1994). We found lower percentage of A. tepida in the seaward sandy sediment which in agreement with previous studies. Samir et al. (2003) showed that A. tepida found in samples located in areas with waters of low energy with muddy or sandy mud bottom sediments. Ferraro et al. (2012) observed that A. parkinsoniana and A. tepida on silty, silty sandy and sandy silty sediments, that is limited to the Gulf of Salerno (South Italy).

The current study shows that A. parkinsoniana is sensitive to the heavy metal pollution which is in accordance with Samir (2000) and Vidovic et al. (2014). Frontalini and Coccioni (2008) reported that A. parkinsoniana has significant negative correlation with $\mathrm{Pb}$ and $\mathrm{Cd}$. Ammonia parkinsoniana is typical for relatively clean environments and appears to poorly tolerate high levels of trace elements (Jorissen, 1988; Frontalini and Coccioni, 2008; Coccioni et al., 2009). Almogi-Labin et al. (1992) recorded that A. parkinsoniana is more sensitive not only to pollution, but also to changes in the natural physical environmental conditions.

The current study indicated that Porosononion spp. increases with the increasing $\mathrm{Cu}$ content, while with decreasing $\mathrm{Pb}$ and $\mathrm{Cd}$ content. Elshanawany et al. (2011) showed that Porosononion spp. is a pollution- tolerant species in polluted Abu Qir Bay, Egypt.

The remarkable appearance of agglutinated foraminifera, represented by $S$. ramose, was recorded mainly at two stations (S4J and S7D). Several previous studies showed the environmental preference of $S$. ramose. It can successfully colonize and dominate the foraminiferal assemblage in low-energy, food limited environments (Koho et al., 2007). Fiorini (2015) also observed that S. ramosa dominated fine grained substrates, stable bottom with low-energy, normal oxygen levels. Some previous studies indicated that $S$. ramosa prefers an epifaunal microhabitat and thrives in stable environments, under well-oxygenated bottom waters and low food supply and concluded its preference to more oligotrophic areas (Altenbach et al., 1988; Koho et al., 2007). Koho et al. (2007) reported that $S$. ramosa can catch and feed on drifting organic particles. A relation between suspended matter load and occurrence of $S$. ramosa in the Gulf of Lions, Western Mediterranean, has also been hypothesised by Schmiedl et al. (2000). This species is practically the only one that was found to survive in the sediments with high Mn concentrations near baritemethane seeps in the Sea of Okhotsk (Khusid et al., 2006). The current study indicates that $S$. ramosa is tolerant to $\mathrm{Pb}-\mathrm{Cd}$ pollution. Although the ecological preference of $S$. ramosa is well known from the previous studies, the relation of $S$. ramosa with pollution was not well documented in the literature. Therefore, this study is considered as a new study in referring to the positive correlation of S. ramosa with $\mathrm{Pb}$ and $\mathrm{Cd}$. Further studies are requested to confirm this relation.

In the present study Miliolids increase in the less polluted, sandy, higher salinity, seaward stations such as S11. Dimiza et al. (2016) reported that miliolids 
displayed significant negative values with heavy metals. Miliolids are negatively correlated with percent mud as well.

In the current study Quinqueloculina spp., Q. lata, Adelosina spp., Elphidium crispum, Elphidium advenum, Miliolinella spp., Miliolinella semicostata, Buccella spp., Rosalina macropora, Nonion spp. and Nonion commune are distributed in the center of RDA diagram. They don't show significant relation with the environmental parameters. Quinqueloculina are more sensitive to environmental pollution (presence of heavy metals), so that in the presence of increasing pollution their abundance decreases (Samir and El-Din, 2001; Jamil, 2001; Ferraro et al., 2006; Valenti et al., 2008). Li et al. (2015) reported that Quinqueloculina spp. is negatively related to (Cr, $\mathrm{Cu}, \mathrm{Ga}, \mathrm{Pb}, \mathrm{Rb}, \mathrm{Zn}$ and $\mathrm{Zr}$ ). In contrast to the previous studies, Romano et al. (2009) reported that $Q$. lata has a positive correlation with $\mathrm{Cu}, \mathrm{Pb}$ and $\mathrm{Zn}$, therefore, it may be considered as a pollution-tolerant species. On the other hand, Elshanawany et al. (2011) reported the sensitivity of Quinqueloculina spp. to pollution, while the tolerance of $Q$. lata to pollution. Romano et al. (2009) reported that $Q$. lata dominated sandy sediments with high concentrations of $\mathrm{Fe}, \mathrm{Pb}, \mathrm{Zn}, \mathrm{Ni}$ and PAHs. They considered it as a pollution tolerant species. Concerning the other environmental parameters, Fiorini (2015) observed that Quinqueloculina prefers coarse grain sediment. Quinqueloculina spp. found in samples collected from depths bathed by turbid inner shelf conditions with some fresh water inflow and sandy bottom sediments (Samir et al., 2003).

In particular miliolids generally prefer high oxygen concentration in the shelf area waters while Elphidium spp. are more tolerant to stressed environmental conditions for changes in salinity and high levels of nutrients (Sen Gupta, 2003). Valenti et al. (2008) concluded that Quinqueloculina spp. and Adelosina spp. appeared to be more sensitive to pollution, whereas Elphidium spp. was more tolerant and can be regarded as opportunistic. E. advenum dominates in shallower water on muddy to sandy substrate in the Adriatic Sea (Jorissen, 1987). Elphidium crispum associates with muddy sands and it has a certain preference for a low input of clay (Murray, 1991; Mendes et al., 2004). Miliolinella spp. is epifaunal foraminifera, it distributes in different environments such as: hypersaline lagoons, normal marine lagoons and marshes, innershelf, and deep-sea (Murray, 2006). Millionella semicostata is dominated in stations which had relatively low concentrations of heavy metals, TOC, but high values of DO (Elshanawany et al., 2011). Buccella spp. is infaunal free genus, distributes in muddy sediment, marine, cold-temperate water, lagoons-innershelf ecosystem (Murray, 2006). Rosalina macropora is distributed in nearshore stations with high energy environmental conditions and low organic matter content (Samir and El-Din, 2001). Nonion spp. migrate to the surface in experiments, if oxygen in sediment decrease. It seems to be more adaptive to change in oxygenation (Panchang et al., 2006). Nonion spp. prefer muddy-silty sediments (Murray, 1991; Nigam and Chaturvedi, 2000). Elshanawany et al. (2011) reported that Nonion spp. is negatively correlated with DO and sand content.

\section{Test deformation}

In the polluted study area, relatively high percentages of deformed tests (up to $\sim 21 \%$ ) and many different abnormal modes (10 modes) are recorded. Moreover, in the present study, the percentage of abnormalities decreases towards the seaward direction; away from the drainage sources. Coccioni et al. (2009) concluded that the relative abundance of abnormal tests may be a useful proxy for the reconstruction of ecological changes especially in paralic environments where it may not be easy to distinguish between the effect of natural stress and anthropogenic impact. They 
showed that statistical analysis reveals a strong relationship between trace elements (in particular $\mathrm{Mn}, \mathrm{Pb}$ and $\mathrm{Hg}$ ) and the occurrence of abnormalities in foraminiferal tests. They also observed greater proportions of abnormal specimens at stations located close to the heaviest polluted industrial zone of Porto Marghera, Italy. Yanko et al. (1998) suggested that heavy metals can penetrate the foraminiferal cell together with food (e.g., algae, bacteria) and then affect the foraminiferal cytoskeleton, which defines the shape of the organism. Le Cadre and Debenay (2006) revealed that an increase in copper contamination may lead to a delay in growth and reproduction, which is then reflected in more frequent dwarfism and the occurrence of new chamber deformations. Cosentino et al. (2013) proposed that anthropogenic trace element pollution could be considered as one of the most important causes of the modifications of foraminiferal assemblages and of the presence of deformed specimens. Romano et al. (2008) revealed a significant correlation between the percentage of deformed Elphidium advena and $\mathrm{Pb}$. Di Leonardo et al. (2007) found a reduction in benthic foraminiferal abundance, an increase in the percentage of abnormal species, and the dominance of opportunistic species in the more affected sediment by pollution.

The presence of abnormal foraminiferal tests has been attributed to environmental fluctuations or extreme values of environmental parameters such as salinity, sedimentation, hydrodynamics changes and mechanical damages (Boltovskoy and Wright, 1976; Geslin et al., 2000; Bergin et al., 2006; Jayaraju et al., 2008; Coccioni et al., 2009). In the current work, if abnormalities are because of the previous fluctuations, abnormal test should has more frequency close to the sea connection at Boughaz El-Meadia, but the opposite trend is recorded. This may increase the probability that these recorded abnormalities are related to pollution.

In the present study, the highest deformation percentage was recorded in Rotaliina (11.24\%). Ammonia tepida is the highest deformed species (7.5\%) within this suborder which is in agreement with Geslin et al. (2002) and Coccioni et al. (2009). Geslin et al. (2002) observed most abnormalities were observed in A. tepida such as protruding chambers, additional chambers or complex forms, aberrant shape or size of chambers, double or triple tests, or complex forms. Miliolina showed very low deformation percentage $(0.1 \%)$. Within this suborder, only $Q$. lata and Quinqueloculina spp. were deformed. This is in contrast to previous literatures such as: Samir and El-Din (2001), Di Leonardo et al. (2007), and Elshanawany et al. (2011). They observed that Miliolids dominated the abnormal assemblages and were reported to be very sensitive to pollution.

A trial to compare the current foraminiferal study with the previous foraminiferal work in Lake Edku has been done; Samir (2000) recorded less percentage of deformed tests with maximum value $5 \%$ in the eastern part of Lake Edku. He reported also that the deformities include only one smaller chamber of the last whorl or twinned specimens. He reported that the abnormalities are too infrequent to indicate environmental stress caused by pollution. We can conclude that the increasing of the percentages of abnormal tests and numbers of deformation, in addition to previously mentioned shifting in foraminiferal assemblages, confirm the increasing level of pollution in the lake in the last decade. This confirms the huge foraminiferal potentiality to trace and monitor pollution. 


\section{CONCLUSION}

The present study investigated the response of benthic foraminiferal assemblages to heavy metal pollution and some environmental parameters in Lake Edku. The resulted data indicate that Lake Edku is highly affected by heavy metal pollution especially $\mathrm{Pb}, \mathrm{Cu}$ and $\mathrm{Cd}$ as it receives huge amounts of domestic, agricultural and industrial wastewater. Benthic foraminiferal assemblages are severely affected by heavy metal pollution. Limited number of living foraminiferal specimens, low density and diversity were observed in Lake Edku. Relatively high percentage of deformed foraminiferal tests $(\sim 21 \%)$ was detected in the lake. In addition, the distribution pattern of benthic foraminifera shows great dominance of Ammonia tepida which supports its tolerance to heavy metals pollution. Ammonia tepida is positively correlated with $\mathrm{Cu}$ and $\mathrm{Cd}$, while it is negatively correlated with $\mathrm{Pb}$. The current study also indicates that Prosononion spp. is tolerant to $\mathrm{Cu}$ pollution, while Saccorhiza ramosa is tolerant to $\mathrm{Pb}-\mathrm{Cd}$ pollution. Ammonia parkinsoniana is considered as a sensitive species, it correlates negatively with all recorded heavy metals. This paper showed that benthic foraminifera can be used as a useful inexpensive tool for biomonitoring of heavy metals pollution of Lake Edku.

\section{ACKNOWLEDGMENT}

Special thanks to the National Commission of Man and the Biosphere Program (MAB) - UNESCO for financial support. We also wish to thank Prof. Gerhard Schmiedl, Professor of Micropaleontology in University of Hamburg, for helping in identification of some foraminiferal species. 


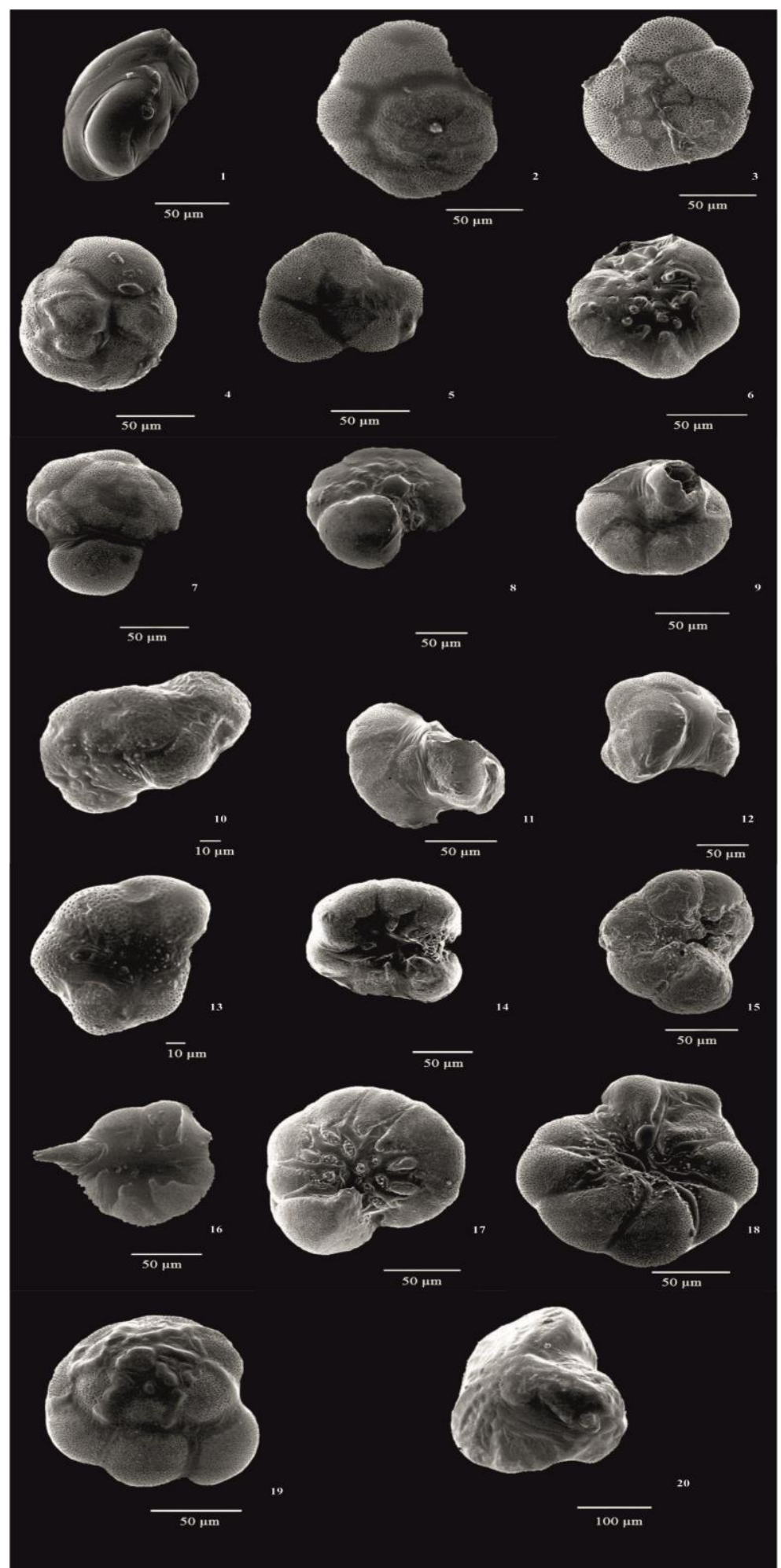

Fig. 5: SEM photographs of deformed benthic foraminifera from Lake Edku, Egypt. 1 Quinqueloculina spp. shows lose milioline coiling, S11J. 2-5 Ammonia tepida spiral view shows not rounded periphery, S1D, S6D, S11D. 6 A. tepida shows protruding and not rounded periphery, S9J. 7-8 A. tepida shows protruding in last chamber, S9J, S11D. 9 A. tepida shows additional chamber, S3J. 10 A. tepida shows additional chamber and distortion in coiling, S1D. 11-12 A. tepida shows twins (broken tests), S11D. 13-15 A. tepida shows abnormal growth, S7D, S10J, S1D. 16 A. tepida shows abnormal growth (spine), S9J. 17 Ammonia parkinsoniana shows abnormal growth, S9D. 18 A. parkinsoniana shows division in last chamber, S1D. $19 A$. parkinsoniana shows spiroconvex shape, S11D. 20 Elphidium advenum shows highly deformed specimen, S11D. 


\section{REFERENCES}

Abdallah, M. A. M. (2012). Phytoremediation of heavy metals from aqueous solutions by two aquatic macrophytes, Ceratophyllum demersum and Lemna gibba L. Environ. Technol., 33: 1609 - 1614.

Abdallah, M. A. M. and Morsy, F. A. E. (2013). Persistent organochlorine pollutants and metals residues in sediment and freshwater fish species cultured in a shallow lagoon, Egypt. Environ. Technol., 34: 2389 - 2399.

Abdel Halim, A. M.; Mahmoud, M. G. O.; Guerguess, M. S. and Tadros, H., R. Z. (2013). Major constituents in Lake Edku water, Egypt. Egy. J. Aqu. Res., 39: 13 $-20$.

Abdel-Moati, M. A. R. and El-Sammak, A. A. (1997). Man-made impact on the geochemistry of the Nile Delta Lakes. A study of metals concentrations in sediments. Water Air Soil Pollut., 97: 413 - 429.

Almogi-Labin, A.; Perelis-Grossovicz, L. and Raab, M. (1992). Living Ammonia froma hypersaline inland pool, Dead Sea area, Israel. J. Foraminiferal Res., 22: $257-266$.

Aloulou, F.; EllEuch, B. and Kallel, M. (2012). Benthic foraminiferal assemblages as pollution proxies in the northern coast of Gabes Gulf, Tunisia. Environ. Monit. Assess., 184: 777 - 795.

Altenbach, A. V.; Unsöld, G. and Walger, E. (1988). The hydrodynamic environment of Saccorhiza ramosa (BRADY). Meyniana., 40: 119 - 135.

Alve, E. (1991). Benthic foraminifera reflecting heavy metal pollution in Sørljord,Western Norway. J. Foraminiferal Res., 34: 1641-1652.

Alve, E. (1995). Benthic foraminiferal distribution and recolonization of formerly anoxic environments in Drammens fjord, southern Norway. Mar. Micropaleontol., 25: $169-86$.

Alve, E., and Murray, J. W. (1994). Ecology and taphonomy of benthic foraminifera in a temperate mesotidal inlet. J. Foraminiferal Res., 24: $18-27$.

Armstrong, H. A. and Brasier, M. D. (2005). Microfossils, $2^{\text {nd }}$ Edition, Blackwell Publishing, $155 \mathrm{pp}$.

Armynot du Châtelet, E. and Debenay, J. P. (2010). The anthropogenic impact on the Western French coasts as revealed by foraminifera: a review. Rev. de Micropaleontol., 53: 129 - 137.

Armynot du Châtelet, E.; Debenay, J. P. and Soulard, R. (2004). Foraminiferal proxies for pollution monitoring in moderately polluted harbours. Env. Poll., 127: $27-40$.

Armynot du Châtelet, E.; Roumazeilles, B.; Riboulleau, A. V. and Trentesaux, A. (2009). Sediment (grain size and clay mineralogy) and organic matter quality control on living benthic foraminifera. Rev. de Micropaleontol., 52: 75 - 84.

Armynot du Châtelet, E.; Gebhardt, K. and Langer, M. R. (2011). Coastal pollution monitoring: Foraminifera as tracers of environmental perturbation in the port of Boulogne-sur-Mer (Northern France). Neues Jahrbuch für Geologie und Paläontologie Abhandlungen, 262: 91 - 116.

Badr, N. B. E. and Fawzy, M. (2008). Bioaccumulation of and Biosorption of heavy metals and phosphorus by Potamegaton pectinatus L. and Ceratophyllum demersum L. in two Nile Delta Lakes. Fresenius Env. Bul., 17: 282 - 292.

Badr, N. B. E. and Hussein, M. M. (2010). An Input/ Output Flux Model of Total Phosphorous in Lake Edku, a Northern Eutrophic Nile Delta Lake. Glob. J. Env. Res., 4: $64-75$. 
Banerji, R. K. (1992). Heavy metals and benthic foraminiferal distribution along Bombay Coast, India. Studies on benthic foraminifera. Sendai, Tokai University Press.

Barakat, A. O.; Mostafa, A.; Wade, T. L.; Sweet, S. T. and El Sayed, N. B. (2011). Distribution and characteristics of PAHs in sediments from the Mediterranean coastal environment of Egypt. Mar. Pollut. Bull., 62: 1969 - 1978.

Barras, C.; Jorissen, F. J.; Labrune, C.; Andral, B. and Boisserye, P. (2014). Live benthic foraminiferal faunas from the French Mediterranean Coast: Towards a new biotic index of environmental quality. Ecol. Indic., 36: 719 - 743.

Bergin, F.; Kucuksezgin, F.; Uluturhan, E.; Barut, I. F.; Meric, E.; Avsar, N. and Nazik, A. (2006). The response of benthic foraminifera and ostracoda to heavy metal pollution in Gulf of Izmir (Eastern Aegean Sea). Estuar. Coast. Shelf Sci., 66: $368-386$.

Boltovskoy, E. and Wright, R. (1976). Recent Foraminifera. In: "The Hague". W. Junk (Ed.). 515 pp.

Burone, L.; Venturini, N.; Sprechmann, P.; Valente, P. and Muniz, P. (2006). Foraminiferal responses to polluted sediments in the Montevideo coastal zone, Uruguay. Mar. Pollut. Bull., 52: 61 - 73.

Buzas, M. A. (1965). The distribution and abundance of foraminifera in Long Island Sound. Smithsonian Miscellaneous Collections, 149: 1- 89.

Buzas, M. A.; Hayek, L. C.; Reed, S. A. and Jett, J. A. (2002). Foraminiferal densities over five years in the Indian River Lagoon, Florida: a model of pulsating patches. J. Foraminiferal Res., 32: $68-92$.

Buzas, M. A.; Hayeka, L. A. C.; Haywardb, B. W.; Grenfellb, H. R. and Sabaab, A. T. (2007). Biodiversity and community structure of deep-sea foraminifera around New Zealand. Deep-Sea Res. I, 54: 1641 - 1654.

Campbell, P. G. C. and Tessier, A. (1989). Biological availability of metals in sediments: analytical approaches. Proceedings of the International Conference on 'Heavy Metals in the Environment', Geneva.

Canadian Councils of Ministers of the Environment (CCME). (2002). Canadian water quality guidelines for the protection of aquatic life. Canadian Water Quality Index 1.0, Technical Report, Winnipeg, Canada.

Cearreta, A. M.; Irabien M. J.; Leorri E.; Yusta I.; Croudace I. W. and Cundy A. B. (2000). Recent anthropogenic impacts on the Bilbao Estuary, northern Spain: geochemical and microfaunal evidence. Estuar. Coast. Shelf Sci., 50: 571 - 92.

Cearreta A. M.; Irabien M. J.; Ulibarri I.; Yusta I.; Croudace I. W. and Cundy A. B. (2002). Recent salt marsh development and natural regeneration of reclaimed areas in the Plentzia Estuary, N Spain. Estuar. Coast. Shelf Sci., 54: 863 - 86.

Cherchi, A.; Da Pelo, S.; Ibba, A.; Mana, D.; Buosi, C. and Floris, N. (2009). Benthic foraminifera response and geochemical characterization of the coastal environment surrounding the polluted industrial area of Portovesme (SouthWestern Sardinia, Italy). Mar. Pollut. Bull., 59: 281 - 96.

Christophoridis, C. E.; Dedepsidis, D. and Fytianos, K. (2009). Occurrence and distribution of selected heavy metals in the surface sediments of Thermaikos Gulf, N. Greece. Assessment using pollution indicators. J. Hazard Mater., 168: 1082 - 1091.

Cimerman, F. and Langer, M. R. (1991). Mediterranean foraminifera: Slovenska akademija znanosti in umetnosti, Ljubljana, $118 \mathrm{pp}$.

Closs, D. and Madeira, M. L. (1968). Seasonal variations of brackish Foraminifera in the Patos lagoon - Southern Brazil, Escuela Geologia Puerto Alegre. Publicação 
Especial., 15: $1-51$.

Coccioni, R. (2000). Benthic foraminifera as bioindicators of heavy metal pollution-a case study from the Goro Lagoon (Italy). In: "Environmental Micropaleontology: The Application of Microfossils to Environmental Geology". Martin, R. E. (Ed.). New York, Kluwer Academic/Plenum Publishers, pp. 71-103.

Coccioni, R.; Frontalini, F.; Marsili, A. and Mana, D. (2009). Benthic foraminifera and trace element distribution: A case-study from the heavily polluted lagoon of Venice (Italy). Mar. Pollut. Bull., 59: 257 - 267.

Cognetti, G. (1992). Colonization of stressed coastal environments. Mar. Pollut. Bull., 24: 247-250.

Cosentino, C.; Pepe, F.; Scopelliti, G.; Calabrò, M. and Caruso, A. (2013). Benthic foraminiferal response to trace element pollution - the case study of the Gulf of Milazzo, NE Sicily (Central Mediterranean Sea). Environ. Monit. Assess., 185: $8777-8802$.

De Nooijer, L. J.; Duijnstee, I. A. P.; Bergman, M. J. N. and van der Zwaan, G. J. (2008). The ecology of benthic foraminifera across the Frisian Front, southern North Sea. Estuar. Coast. Shelf Sci., 78: 715 - 726.

Debenay, J. P. (2009). Foraminifera, In: "Environmental Assessment of Estuarine Ecosystems: a case study”. Amiard-Triquet, C. \& Rainbow, P. S. (Eds.). Taylor and Francis Group, Boca Raton, London New York, pp. 255-280.

Debenay, J. P.; Millet, B. and Angelidis, M. (2005). Relationships between foraminiferal assemblages of hydrodynamics in the Gulf of Kalloni (Greece). J. Foraminiferal Res., 35: $327-343$.

Debenay, J. P. and Fernandez, J. M. (2009). Benthic foraminifera records of complex anthropogenic environmental changes combined with geochemical data in a tropical bay of New Caledonia (SW Pacific). Mar. Pollut. Bull., 59: 311 - 322.

Degetto, S.; Schintu, M.; Contu, A. and Sbrignadello, G. (1997). Santa Gilla lagoon (Italy): a mercury sediment pollution case study. Contamination assessment and restoration of the site. Sci. Total Environ., 204: 49 - 56.

Di Leonardo, R.; Bellanca, A.; Capotondi, L.; Cundy, A. and Neri, R. (2007). Possible impacts of $\mathrm{Hg}$ and $\mathrm{PAH}$ contamination on benthic foraminiferal assemblages: an example from the Sicilian coast, central Mediterranean. Sci. Total Environ., 388: $168-18$.

Dimiza, M. D.; Triantaphyllou, M. V.; Koukousioura, O.; Hallock, P.; Simboura, N.; Karageorgis, A. P. and Papathanasiou, E. (2016). The Foram Stress Index: A new tool for environmental assessment of soft-bottom environments using benthic foraminifera. A case study from the Saronikos Gulf, Greece, Eastern Mediterranean. Ecol. Indic., 60: 611 - 621.

El Zokm, G. M.; Okbah, M. A. and Younis, A. M. (2015). Assessment of heavy metals pollution using AVSSEM and fractionation techniques in Edku Lagoon sediments, Mediterranean Sea, Egypt. J. Environ. Sci. Health, 50: 571 - 584.

El-Said, G. F.; Draz, S. E. O.; El-Sadaawy, M. M. and Moneer, A. A. (2014). Sedimentology, geochemistry, pollution status and ecological risk assessment of some heavy metals in surficial sediments of an Egyptian lagoon connecting to the Mediterranean Sea. J. Environ. Sci. Health, Part A, 49: 1029 - 1044.

Elshanawany, R.; Ibrahim, M. I.; Milker, Y.; Schmiedl, G.; Badr, N.; Kholeif, S. E. A. and Zonneveld, K. A. F. (2011). Anthropogenic impact on benthic foraminifera, Abu-Qir Bay, Alexandria, Egypt. J. Foraminiferal Res., 41: 326 - 348.

Ferraro, L.; Sprovieri, M.; Alberico, I.; Lirer, F.; Prevedello, L. and Marsella, E. 
(2006). Benthic foraminifera and heavy metals distribution: a case study from the Naples Harbour (Tyrrhenian Sea, Southern Italy). Env. poll., 142: 274 287.

Ferraro, L.; Alberico, I.; Lirer, F. and Vallefuoco, M. (2012). Distribution of benthic foraminifera from the southern Tyrrhenian continental shelf (South Italy). Rend. Fis. Acc. Lincei., 23: 103 - 119.

Fiorini, F. (2015). Recent benthic foraminifera from the Caribbean continental slope and shelf off west of Colombia. J. South Am. Earth Sci., 60: 117 - 128.

Foster, W., J.; Armynot du Châtelet, E. and Rogerson, M. (2012). Testing benthic foraminiferal distributions as a contemporary quantitative approach to biomonitoring estuarine heavy metal pollution. Mar. Pollut. Bull., 64: 1039 1048.

Frontalini, F. and Coccioni, R. (2008). Benthic foraminifera for heavy metal pollution monitoring: a case study from the central Adriatic Sea coast of Italy. Estuar. Coast. Shelf Sci., 76: $404-417$.

Frontalini, F. and Coccioni, R. (2011). Benthic foraminifera as bioindicators of pollution: A review of Italian research over the last three decades. Rev. de micropaléontol., 54: 115 - 127.

Frontalini, F.; Buosi, C.; Pelo, S.; Coccioni, R.; Cherchi, A. and Bucci, C. (2009). Benthic foraminifera as bio-indicators of trace element pollution in the heavily contaminated Santa Gilla lagoon (Cagliari, Italy). Mar. Pollut. Bull., 58: 858 877.

Frontalini, F.; Coccioni, R. and Bucci, C. (2010). Benthic foraminiferal assemblages and trace element contents from the lagoons of Orbetello and Lesina. Environ. Monit. Assess., 170: 245 - 260.

Frontalini, F.; Semprucci, F.; Coccioni, R.; Balsamo, M.; Bittoni, P. and CovazziHarriague, A. (2011). On the quantitative distribution and community structure of the meio and macrofaunal communities in the coastal area of the Central Adriatic Sea (Italy). Environ. Monit. Assess., 180: 325 - 344.

Geslin, E.; Stouff, V.; Debenay, J. P. and Lesourd, M. (2000). Environmental variation and foraminiferal test abnormalities. In: "Environmental Micropaleontology". Martin, R. E. (Ed.). New York, Kluwer Academic/Plenum Publishers, pp. 91215.

Geslin, E.; Debenay, J. P.; Duleba, W. and Bonetti, C. (2002). Morphological abnormalities of foraminiferal tests in Brazilian environments: comparison between polluted and non-polluted areas. Mar. Micropaleontol., 45: $151-168$.

Geslin, E.; Barras, C.; Langlet, D.; Nardelli, M. P.; Kim, J.; Bonnin, J.; Metzger, E. and Jorissen , F. J. (2014). Survival, reproduction and calcification of three benthic foraminiferal species in response to experimentally induced hypoxia. In: "Approaches to study living foraminifera collection, maintenance and experimentation". Springer, pp. 163-193.

Gu, J.; Salem, A. and Chen, Z. (2013). Lagoons of the Nile delta, Egypt, heavy metal sink: With a special reference to the Yangtze estuary of China. Estuar. Coast. Shelf Sci., 117: $282-292$.

Hammer, O.; Harper, D. A. T. and Ryan, P. D. (2008). PAST: PAlaeontological STatistics ver. 1.88., Software Documentation.

Ibrahim, M. K. (1994). Geochemical cycle of phosphorous in Lake Edku. M.Sc. Thesis, Faculty of Science, Alexandria University, 243 p.

Jamil, K. (2001). Bioindicators and Biomarkers of Environmental pollution and Risk Assessment, Science Publishers, Enfield, New Hampshire, USA. 
Jayaraju, N. and Reddy, K. R. (1996). Impact of pollution on coastal zone monitoring with benthic foraminifera of Tuticorin, southeast coast of India. Indian J. Mar. Sci., 25: $376-378$.

Jayaraju, N.; Reddy, B. C. S. R. and Reddy, K. R. (2008). The response of benthic foraminifera to various pollution sources: A study from Nellore coast, east coast of India. Environ. Monit. Assess., 142: 319 - 323.

Jorissen, F.J. (1987). The distribution of benthic foraminifera in the Adriatic Sea. Mar. Micropaleontol., 12: $21-48$.

Jorissen, F. (1988). Benthic foraminifera from the Adriatic Sea; principles of phenotypic variation. Utrecht Micropaleontol. Bul., 37, 174.

Khalil, M. K. H. and Rifaat, A. E. (2013). Seasonal fluxes of phosphate across the sediment-water interface in Edku Lagoon, Egypt. Oceanologia, 55: 219 - 233.

Khalil, M. K.; El Zokm, G. M.; Fahmy, M. A.; Said, T. O. and Shreadah, M. A. (2013). Geochemistry of Some Major and Trace Elements in Sediments of Edku and Mariut Lakes, North Egypt. World Appl. Sci. J., 24: 282 - 294.

Khusid, T. A.; Domanov, M. M. and Svininnikov, A. M. (2006). Features of the Species Composition and Distribution of Foraminifers in the Deryugin Basin (Sea of Okhotsk). Izvestiya Rossiiskoi Akademii Nauk -Seriya Biologicheskaya, 2: $217-224$.

Koho, K. A.; Kouwenhoven, T. J.; de Stigter, H. C. and van der Zwaan, G. J. (2007). Benthic foraminifera in the Nazaré Canyon, Portuguese continental margin: Sedimentary environments and disturbance. Mar. Micropaleontol., 66: 27 - 51.

Le Cadre, V. and Debenay, J. (2006). Morphological and cytological responses of Ammonia (foraminifera) to copper contamination: Implication for the use of foraminifera as bioindicators of pollution. Env. Poll., 143: 304 - 317.

Leps, J. and Smilauer, P. (2005). Multivariate analysis of ecological data using CANOCO Cambridge University Press, Cambridge.

Leyer, I. and Wesche, K. (2007). Multivariate Statistik in der Ökologie, Springer, Berlin Heidelberg.

Li, T., Xiang, R. and Li, T. (2014). Influence of trace metals in recent benthic foraminifera distribution in the Pearl River Estuary. Mar. Micropaleontol., 108: $13-27$.

Li, T.; Li, X.; Zhong, H.; Yang, C.; Sun, G. and Luo, W. (2015). Distribution of trace metals and the benthic foraminiferal assemblage as a characterization of the environment in the north Minjiang River Estuary (Fujian, China). Mar. Pollut. Bull., 90: 227 - 241.

Liu, W.; Zhang, Q. and Liu, G. (2011). Effects of watershed land use and lake morphometry on trophic state of Chinese lakes: implications for eutrophication control. Clean - Soil, Air, Water, 39: 35 - 42.

Loeblich, A. R. and Tappan, H. (1987). Foraminiferal Genera and their Classification. New York, Van Nostrand Reinhold Comp, 2, 1182 pp.

Martins, V.; Ferreira da Silva, E.; Sequeira, C.; Rocha, F. and Duarte, A. C. (2010). Evaluation of the ecological effects of heavy metals on the assemblages of benthic foraminifera of the canals of Aveiro (Portugal). Estuar. Coast. Shelf Sci., 87: $293-304$.

Martins, V. A.; Frontalini, F.; Tramonte, K. M.; Figueira, R. C. L.; Miranda, P.; Sequeira, C.; Fernández-Fernández, S.; Dias, J. A.; Yamashita, C.; Renó, R.; Laut, L. L. M.; Silva, F. S.; Rodrigues, M. A. C.; Bernardes, C.; Nagai, R.; Sousa, S. H. M.; Mahiques, M.; Rubio, B.; Bernabeu, A.; Rey, D. and Rocha, F. (2013). Assessment of the health quality of Ria de Aveiro (Portugal): Heavy 
metals and benthic foraminifera. Mar. Pollut. Bull., 70: 18 - 33.

Masoud, M. S.; Elewa, A. A.; Ali, A. E. and Mohamed, E. A. (2005). Distribution of some metals concentrations in water and sediments of Lake Edku, Egypt. Bul. Chem.Tech. Maced., 24: $21-34$.

McGann, M.; Alexander, C. R. and Bay, S. M. (2003). Response of benthic foraminifers to sewage discharge and remediation in Santa Monica Bay, California. Mar. Env. Res., 56: 299 - 342.

Mendes, I.; Gonzalez, R.; Dias, J. M. A.; Lobo, F. and Martins, V. (2004). Factors influencing recent benthic foraminifera distribution on the Guadiana shelf (Southwestern Iberia). Mar. Micropaleontol., 51: 171 - 192.

Milker, Y.; Horton, B. P.; Vane, C. H.; Engelhhart, S. E.; Nelson, A. R.; Witter, R. C.; Khan, N. S. and Bridgeland, W. T. (2015). Annual and seasonal distribution of intertidal foraminifera and stable carbon isotope geochemistry, Bandon Marsh, Oregon, USA. J. Foraminiferal Res., 45: 146 - 166.

Morvan, J.; Debenay, J. P.; Jorissen, P.; Redois, F.; Bénéteau, E.; Delplancke, M. and Amato, A. S. (2006). Patchiness and life cycle of intertidal foraminifera: Implication for environmental and paleoenvironmental interpretation. Mar. Micropaleontol., 61: $131-154$.

Munsel, D.; Kramar, U.; Dissard, D.; Nehrke, G.; Bijma, J.; Reichart, G. J. and Neumann, T. (2010). Heavy metal incorporation in foraminiferal calcite: results from multi-element enrichment culture experiments with Ammonia tepida. Biogeosciences, 7: 2339 - 2350.

Murray, J. W. (1991). Ecology and paleoecology of benthic foraminifera. Routledge, USA, $40 \mathrm{pp}$.

Murray, J. W. (2006). Ecology and Applications of Benthic Foraminifera. Cambridge University Press.

Murray, J. W. and Alve, E. (2000). Major aspects of foraminiferal variability (standing crop and biomass) on a monthly scale in an intertidal zone. J. Foraminiferal Res., 30(3): 177 - 191.

Naidu, T. Y.; Kesavakumar, G. V. and Rama Krishna B. (2000). Benthic foraminifera as a tool for monitoring coastal pollution at some sites in and around Visakhapatnam. Proceedings of national seminar on environmental geology and waste management, pp. $157-9$.

Nigam, R. and Chaturvedi, S. K. (2000). Foraminiferal study from Kharo creek, Kachchh (Gujarat), North West coast of India. Indian J. Mar. Sci., 29: 133 138.

Nigam, R.; Nayak, G. N. and Naik S. (2002). Does mining pollution affect foraminiferal distribution in Mandovi estuary, Goa, India? Rev. de Paleobiol., 2: $73-677$.

Nikulina, A.; Polovodova, I. and Schonfeld, J. (2008). Foraminiferal response to environmental changes in Kiel Fjord, SW Baltic Sea. eEarth, 3: 37 - 49.

Orabi, O. H.; El-Badry, A. A. and Badr El-Din, A. M. (2017). Benthic foraminifera for heavy metal pollution monitoring: A case study from Burullus Lagoon of Egypt. Mar. Pollu. Bul., 15: 411 - 417.

Panchang, R.; Nigam, R.; Linshy, V.; Rana, S. S. and Ingole, B. (2006). Effect of oxygen manipulations on benthic foraminifera: A preliminary experiment. Indian J. Mar. Sci., 35: 235 - 239.

Papagiannis, I.; Kagalou, I.; Leonardos, J.; Petridis, D. and Kalfakakou, V. (2004). Copper and zinc in four fresh water fish species from Lake Pamvotis Greece. Environ. Int., 30: 357 - 362. 
Qiao, Y.; Yang, Y.; Gu, J. and Zhao, J. (2013). Distribution and geochemical speciation of heavy metals in sediments from coastal area suffered rapid urbanization, a case study of Shantou Bay, China. Mar. Pollut. Bull., 68: 140 146.

Romano, E.; Bergamin, L.; Finoia, M.; Carboni, M.; Ausili, A. and Gabellini, M. (2008). Industrial pollution at Bagnoli (Naples, Italy): Benthic foraminifera as a tool in integrated programs of environmental characterisation. Mar. Pollut. Bull., 56: 439 - 457.

Romano, E.; Bergamin, L.; Ausili, A.; Pierfranceschi, G.; Maggi, C. and Gabellini, M. (2009). The impact of the Bagnoli industrial site (Naples, Italy) on sea-bottom environment. Chemical and textural features of sediments and the related response of benthic foraminifera. Mar. Pollut. Bull., 59: 245 - 256.

Sadough, M.; Ghane, F.; Manouchehri, H.; Moghaddasi, B. and Beikaee, H. (2013). Identification and Abundance of Benthic Foraminifera in the Sediments from Fereidoonkenar to Babolsar of Southern Caspian Sea. Turkish J. Fish. Aqu. Sci., 13: $79-86$.

Samir, A. M. (2000). The response of benthic foraminifera and ostracods to various pollution sources: a study from two lagoons in Egypt. J. Foraminiferal Res., 30: $83-98$.

Samir, A. M. and El-Din, A. B. (2001). Benthic foraminiferal assemblages and morphological abnormalities as pollution proxies in two Egyptian bays. Mar. Micropaleontol., 41: 193 - 227.

Samir, A. M.; Abdou, H. F.; Zazou, S. M. and El-Menhawey, W. H. (2003). Cluster analysis of recent benthic foraminifera from the north western Mediterranean coast of Egypt. Rev. de Micropaléontol., 46: 111 - 130.

Sanita di Toppi, L. and Gabbrielli, R. (1999). Response to cadmium in higher plants. Environ. Exper. Bot., 41, 105 - 130.

Schmiedl, G.; de Bovée, F.; Buscail, R.; Charrière, B.; Hemleben, C.; Medernach, L. and Picon, P. (2000). Trophic control of benthic foraminiferal abundance and microhabitat in the bathyal Gulf of Lions, western Mediterranean Sea. Mar. Micropaleontol., 40: $167-188$.

Sen Gupta, B. K. E. (2003). Modern Foraminifera. Kluwer Academic Publishers, Dordrecht.

Serandrei Barbero, R.; Morisieri, M.; Carbognin, L. and Donnici, S. (2003). An inner shelf foraminiferal fauna and its response to environmental processes (Adriatic Sea, Italy). Rev. Esp. Micropaleontol., 35: 241 - 264.

Setty, M. G. A. P. (1982). Pollution effects monitoring with foraminifera as indices in the Thana Creek, Bombay area. Int. J. Environ. Stud., 18: 205 - 9.

Sgarrella, F. and Moncharmont-Zei, M. (1993). Benthic Foraminifera of the Gulf of Naples (Italy): systematics and autoecology. Bollettino della Societa' Paleontologica Italiana, 32: 145 - 264.

Shakweer, L. (2006). Impacts of drainage water discharge on the water chemistry of Lake Edku. Egy. J. Aqu. Res., 32: 264 - 282.

Shreadah, M. A.; Abdel Ghani, S. A.; Taha, A. E. S.; Ahmed, A. E. M. M. and Hawash, H. B. I. (2012). Mercury and Methyl Mercury in Sediments of Northern Lakes-Egypt. J. Env. Prot., 3: $254-261$.

Tang, C. W.; Ip, C. C.; Zhang, G.; Shin, P. K. S.; Qian, P. and Li, X. (2008). The spatial and temporal distribution of heavy metals in sediments of Victoria Harbour, Hong Kong. Mar. Pollut. Bull., 57: 816 - 825.

Ter Braak, C. J. F. and Smilauer, P. (2002). CANOCO Reference Manual and User's 
Guide to Canoco for Windows: Software for Canonical Community Ordination. Versão 4.5. Microcomputer Power, Ithaca, NY. 500 pp.

U.S. EPA. (1999). U.S. Environmental Protection Agency. Screening level ecological risk assessment protocol for hazardous waste combustion facilities, v. 3, Appendix E: Toxicity reference, values. EPA530-D99-001C.

Valenti, D.; Tranchina, L.; Brai, M.; Caruso, A.; Cosentino, C. and Spagnolo, B. (2008). Environmental metal pollution considered as noise: Effects on the spatial distribution of benthic foraminifera in two coastal marine areas of Sicily (Southern Italy). Ecol. Model., 213: 449 - 462.

Vidovic, J.; Dolenec, M.; Dolenec, T.; Karamarko, V. and Rozic, P. (2014). Benthic foraminifera assemblages as elemental pollution bioindicator in marine sediments around fish farm (Vrgada Island, Central Adriatic, Croatia). Mar. Pollut. Bull., 83(1): 198 - 213.

Vilella, C. G.; Batista, D. S.; Baptista-Neto, J. A.; Crapez, M. and Mcallister, J. J. (2004). Benthic foraminífera distribution in high polluted sediments from Niterói Harbor (Guanabara Bay), Rio de Janeiro, Brazil. An. Acad. Bras. Ciênc., 76: 161 - 171.

Wade, T. L.; Brooks, J. M.; Kennicut, M. C.; McDonald, T. J.; Sericano, J. L. and Jackson, T. L. (1993). GERG Trace Metals and Organic Contaminants Analytical Techniques. In: "Sampling and Analytical Methods of the National Status and Trend Program. National Benethic Surveillance and Mussel Watch Projects 1984-1992”. Lauenstein, G. G. \& Cantillo, A. Y. (Eds.). NOAA Technical Memorandum NOS ORCA 71. Silver Spring, MD, pp. 121-139.

Walton, W. R. (1952). Techniques for recognition of living foraminifera, Contribution of Cushman, Foundation Foraminiferal Research, 3: 56 - 60.

Walton, W. R. (1955). Ecology of living benthonic Foraminifera, Todos Santos Bay, Baja California. J. PALEONTOL., 29: 952-1018.

Watkins, J. G. (1961). Foraminiferal ecology around the Orange County California, ocean sewer outfall. Micropal., 7: $199-206$.

Yanko, V.; Kroneeld, J. and Flexer, A. (1994). Response of benthic foraminifera to various pollution sources: implications for pollution monitoring. $\mathrm{J}$. Foraminiferal Res., 24: $1-17$.

Yanko V.; Ahmad, M. and Kaminski, M. (1998). Morphological deformities of benthic foraminiferal test in response to pollution by heavy metals: implications for pollution monitoring. J. Foraminiferal Res., 28: 177 - 200.

Yanko, V.; Arnold, A. and Parker, W. (2003). Effects of Marine Pollution on Benthic Foraminifera. In: "Modern Foraminifera, Part II". Sen Gupta, B. K. (Ed.). New York: Kluwer Academic Publishers, pp. 217-235. 


\section{ARABIC SUMMARY}

استخدام توزيع الفورامينيفرا القاعية والعناصر الثقيلة للتوصيف البيئي لبحيرة ادكو بجمهورية مصر العربية رحاب الشنواني 1,2 - بسنت نايل1 ـ منال فوزي 1

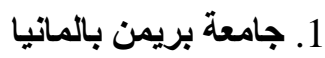
2. 2لبة العلوم، جامعة الاسكندرية، مصر باليا

تتعرض بحيرة ادكو للتلوث بالملوثات الزر اعية والصناعية. و عليه تقوم هذه الدراسة بتقييم ناثر الفورامينيفرا

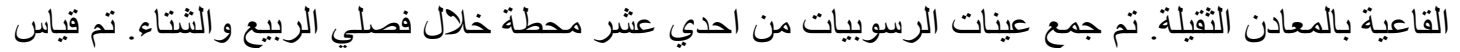

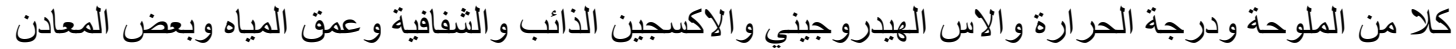

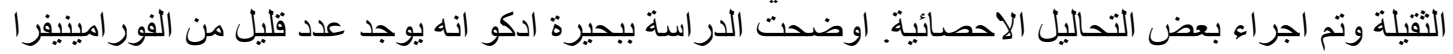

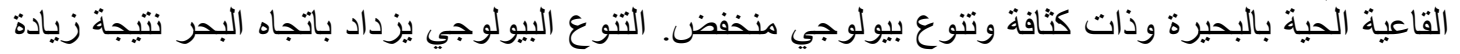

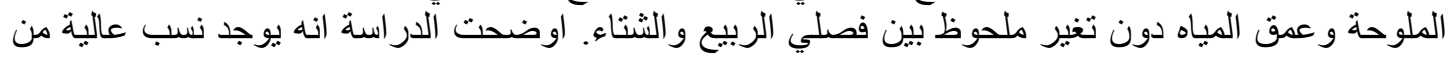

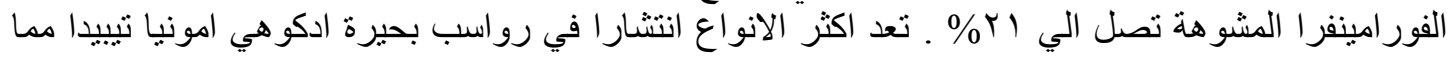

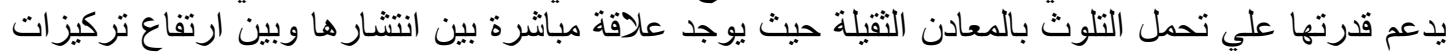

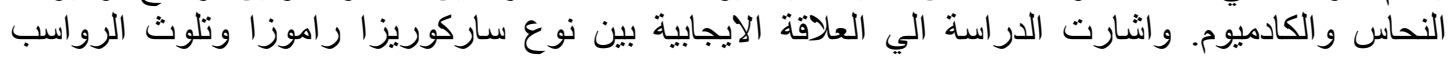

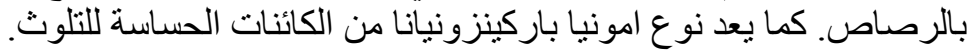

